\title{
Combined Effects of Experimental Acidification and Eutrophication on Reef Sponge Bioerosion Rates
}

\section{OPEN ACCESS}

Edited by:

Hajime Kayanne,

The University of Tokyo, Japan

Reviewed by:

Max Wisshak,

Senckenberg Nature Research

Society, Germany

Susana Enríquez,

National Autonomous University of

Mexico, Mexico

*Correspondence:

Alice E. Webb

alice.webb@nioz.nl

Specialty section:

This article was submitted to

Coral Reef Research,

a section of the journal

Frontiers in Marine Science

Received: 06 June 2017 Accepted: 12 September 2017 Published: 26 September 2017

Citation:

Webb AE, van Heuven SMAC, de Bakker DM, van Duyl FC, Reichart G-J and de Nooijer LJ (2017) Combined Effects of Experimental Acidification and Eutrophication on Reef Sponge Bioerosion Rates.

Front. Mar. Sci. 4:311.

doi: 10.3389/fmars.2017.00311

\begin{abstract}
Alice E. Webb ${ }^{1 *}$, Steven M. A. C. van Heuven ${ }^{1}$, Didier M. de Bakker ${ }^{2}$, Fleur C. van Duyl ${ }^{2}$, Gert-Jan Reichart ${ }^{3,4}$ and Lennart J. de Nooijer ${ }^{1}$

1 Department of Ocean Systems, NIOZ Royal Netherlands Institute for Sea Research and Utrecht University, Texel, Netherlands, ${ }^{2}$ Department of Marine Microbiology and Biogeochemistry, NIOZ Royal Netherlands Institute for Sea Research and Utrecht University, Texel, Netherlands, ${ }^{3}$ Department of Ocean Systems, NIOZ Royal Netherlands Institute for Sea Research, Texel, Netherlands, ${ }^{4}$ Department of Earth Sciences, Faculty of Geosciences, Utrecht University, Utrecht, Netherlands
\end{abstract}

Health of tropical coral reefs depends largely on the balance between constructive (calcification and cementation) and destructive forces (mechanical-chemical degradation). Gradual increase in dissolved $\mathrm{CO}_{2}$ and the resulting decrease in carbonate ion concentration ("ocean acidification") in ocean surface water may tip the balance toward net mass loss for many reefs. Enhanced nutrients and organic loading in surface waters ("eutrophication"), may increase the susceptibility of coral reef and near shore environments to ocean acidification. The impacts of these processes on coral calcification have been repeatedly reported, however the synergetic effects on bioerosion rates by sponges are poorly studied. Erosion by excavating sponges is achieved by a combination of chemical dissolution and mechanical chip removal. In this study, Cliona caribbaea, a photosymbiont-bearing excavating sponge widely distributed in Caribbean reef habitats, was exposed to a range of $\mathrm{CO}_{2}$ concentrations, as well as different eutrophication levels. Total bioerosion rates, estimated from changes in buoyant weights over 1 week, increased significantly with $\mathrm{pCO}_{2}$ but not with eutrophication. Observed chemical bioerosion rates were positively affected by both $\mathrm{pCO}_{2}$ and eutrophication but no interaction was revealed. Net photosynthetic activity was enhanced with rising $\mathrm{pCO}_{2}$ but not with increasing eutrophication levels. These results indicate that an increase in organic matter and nutrient renders sponge bioerosion less dependent on autotrophic products. At low and ambient $\mathrm{pCO}_{2}$, day-time chemical rates were $\sim 50 \%$ higher than those observed at night-time. A switch was observed in bioerosion under higher $\mathrm{pCO}_{2}$ levels, with night-time chemical bioerosion rates becoming comparable or even higher than day-time rates. We suggest that the difference in rates between day and night at low and ambient $p \mathrm{CO}_{2}$ indicates that the benefit of acquired energy from photosynthetic activity surpasses the positive effect of increased $\mathrm{pCO}_{2}$ levels at night due to holobiont respiration. This implies that excavation must cost cellular energy, by processes, such as ATP usage for active $\mathrm{Ca}^{2+}$ and/or active proton pumping. Additionally, competition for dissolved inorganic carbon species may occur between bioerosion and photosynthetic activity by the symbionts. Either way, the observed changing role of symbionts in bioerosion can be attributed to enhanced photosynthetic activity at high $\mathrm{pCO}_{2}$ levels.

Keywords: sponge bioerosion, ocean acidification, eutrophication, coral reef, diurnal rhythm, sponge symbionts 


\section{INTRODUCTION}

The ocean serves as the largest sink of anthropogenic $\mathrm{CO}_{2}$ on earth after the atmosphere itself. Since the beginning of the industrial revolution, it has taken up $\sim 28 \%$ of the emitted anthropogenic $\mathrm{CO}_{2}$ (Le Quéré et al., 2015). The cumulative uptake of atmospheric carbon dioxide by the ocean has increased the total marine inorganic carbon concentration, reduced $\mathrm{pH}$ and consequently decreased the $\mathrm{CaCO}_{3}$ saturation state. Together, these effects are termed ocean acidification (OA) and it is predicted that average surface ocean $\mathrm{CaCO}_{3}$ saturation state will have decreased by $25-50 \%$ at the end of the current century, depending on the emission scenario (Hoegh-Guldberg et al., 2007; Gattuso and Hansson, 2011; Veron, 2011; Le Quéré et al., 2013).

Eutrophication, caused by increasing release of nutrients and organic material in surface waters, represents an additional threat to near-shore and coral reef environments. Recent studies have shown that local anthropogenic disturbances, such as nutrient and organic rich run-offs from agriculture and coastal development, as well as the input of poorly treated waste waters (Gast et al., 1999; Lapointe and Mallin, 2011; Govers et al., 2014) have caused the average $p \mathrm{CO}_{2}$ of coral reefs to increase $\sim 3.5$ fold faster throughout the globe over the past 20 years compared to the open ocean. This is suggested to be caused by a shift in the metabolic balance of coral reef ecosystems (Cai et al., 2011; Cyronak et al., 2014; Yeakel et al., 2015). Such anthropogenic input also promotes growth of opportunistic organisms, such as sponges, macroalgae, turf algae and/or benthic cyanobacteria (Holmes, 2000; Kuffner and Paul, 2001; Gorgula and Connell, 2004; Vermeij et al., 2010), potentially resulting also in major shifts in benthic community compositions (Hughes, 1994; Bruno et al., 2009; De Bakker et al., 2017).

Reef bioerosion by sponges and other bioeroding organisms (Wisshak and Tapanila, 2008) plays an important role in regulating the carbonate budget of coral reefs (Perry et al., 2014). Although the negative effects of OA on production of $\mathrm{CaCO}_{3}$ (calcification) by corals are widely documented (Gattuso et al., 1998; Kleypas and Langdon, 2006; Hoegh-Guldberg et al., 2007; Ries et al., 2009; Pandolfi et al., 2011; Dove et al., 2013), its impact on biologically induced carbonate dissolution and mechanical destruction have been understudied (Zundelevich et al., 2007; Fang et al., 2013a; Wisshak et al., 2014; Enochs et al., 2015; Schönberg et al., 2017) and has so far not been quantified in combination with eutrophication.

Bioeroding sponges contribute between 60 and $90 \%$ of total macroborer activity on coral reefs and their (surface-normalized) erosion rates have been found to equal and even surpass calcification rates of hermatypic corals (MacGeachy and Stearn, 1976; Hudson, 1977; Edinger et al., 2000; Carballo et al., 2008; Perry et al., 2014). Bioeroding sponges use a combination of chemical dissolution and mechanical $\mathrm{CaCO}_{3}$ chip removal to erode coral substrate (Nasonov, 1924; Rützler and Rieger, 1973; Pomponi, 1980). It is hypothesized that specialized cells of the bioeroding sponges are able to lower the $\mathrm{pH}$ at selected sites to promote controlled aragonite dissolution, thereby creating cavities in which the sponge grows. The mechanisms by which sponges dissolve carbonate has however remained elusive since this etching interface is not directly accessible. Several of the most competitive bioeroding sponges harbor endosymbiotic dinoflagellate zooxanthellae and this symbiosis has been shown to enhance bioerosion in light (Hill, 1996; Fang et al., 2016). This raises the question further as to how symbionts enhance bioerosion. Geochemically, this is paradoxical because the autotrophic symbionts would tend to increase $\mathrm{pH}$ and enhance carbonate precipitation rather than dissolution (Garcia-Pichel et al., 2010).

If the chemical composition of the fluid at these sites is related to that of seawater, a reduction in ambient saturation state may lower energetic costs for the sponge to create a microenvironment that is undersaturated for $\mathrm{CaCO}_{3}$, in which the aragonite skeleton may subsequently dissolve and chips are dislodged. Schönberg (2008) provided a first glimpse of a $\mathrm{pH}$ gradient toward the etching sites using micro-sensors which may indicate that sponges do indeed alter the chemistry at the site of bioerosion. Although the underlying physiological and mechanical processes employed by the sponges to erode are currently unknown, a number of studies have shown that an increase in $p \mathrm{CO}_{2}$ of the ambient water results in increased bioerosion rates (Wisshak et al., 2012, 2013; Duckworth and Peterson, 2013; Fang et al., 2013a), suggesting that changes in seawater chemistry directly affect the saturation state at the site where the coral aragonite is dissolved.

Since eutrophication may increase effects of OA in coastal waters, we here assess the potential combined effects on bioerosion rates (both chemical and mechanical) of the sponge Cliona caribbaea Carter, 1882. C. caribbaea is found abundantly in the Caribbean and is a representative of the "Cliona viridis species complex," including clionaids that form a symbiosis with the dinoflagellates of the genus Symbiodinium (Schönberg, 2000). These photosynthetic symbionts (zooxanthellae) provide sponges with a significant fraction of their carbon and energy via photosynthesis (Weisz et al., 2010; Fang et al., 2014). Since this affects diurnal patterns in the holobiont metabolism (Freeman and Thacker, 2011), bioerosion rates by C. caribbaea were determined at day and night.

\section{MATERIALS AND METHODS Sample Collection}

In December 2015, samples containing the bioeroding sponge Cliona caribbaea were retrieved from dead coral substrate (Diploria spp.), found at a water depth between 3 and $5 \mathrm{~m}$ ( $S=34$ and $T=28^{\circ} \mathrm{C}$ ) at the leeward side of the island of St. Eustatius, Caribbean Netherlands $\left(17.4890^{\circ} \mathrm{N}, 62.9736^{\circ}\right.$ $\mathrm{W})$. Annual mean seawater temperature is $27.6^{\circ} \mathrm{C}$, varying between $26.1^{\circ} \mathrm{C}$ in Feb-Mar and $28.2^{\circ} \mathrm{C}$ in Sept-Oct. Samples were collected using an air drill and hole saw (inner diameter: $40 \mathrm{~mm}$ ) and transported submerged in ambient SW to an onshore $\mathrm{CO}_{2}$-controlled experimental set-up. The sponge-infested cores were placed in large flow-through tanks $(50 \mathrm{~L})$ for 1 week to allow them to recover from collection and transport. Samples of coral skeleton without bioeroding sponges served as control substrate for the incubations. Collected cores were 
brushed delicately with a soft brush to remove any nonsponge organisms. The experiment lasted 1 week from December 23 to December 30 2015, excluding acclimatization to the various $p \mathrm{CO}_{2}$ scenarios, which was performed gradually over 6 days from the December 17 to December 22. Each core was photographed at the start (before acclimatization) and at the end of the experiment to assess physical variations throughout the experiment. In addition, fluorescein was released near the ostia half way through the experiment to make sure sponges were still filtering.

\section{Experimental Setup}

Sand-filtered nearshore seawater was continuously supplied to four 200-L barrels in which the $p \mathrm{CO}_{2}$ of the water was maintained at four different levels. Water from each of the four barrels was continuously pumped into nine aquaria of $12 \mathrm{~L}$ each, resulting in a total of 36 aquaria distributed across three tables (A, B, and C). Three different levels of dissolved organic and inorganic matter concentrations were maintained in three sets of three aquaria within each $\mathrm{pCO}_{2}$ scenario (Figure 1). All aquaria received an irradiance at levels and spectral quality similar to in-situ conditions, as provided by sunlight passing through Marine Blue filters (\#131; Lee filters), and neutral density shading cloth. The aquaria were placed in a $5 \mathrm{~cm}$ high flow-through bath of seawater to minimize temperature fluctuations.

Carbonate chemistry of the water in the four barrels was manipulated using a feedback control system developed inhouse, consisting of a central $\mathrm{xCO}_{2}$ sensor (LICOR Inc. model LI-7000), $\mathrm{CO}_{2}$ injectors, $\mathrm{CO}_{2}$ scrubbers and a control computer. In each barrel, water was adjusted to desired $p \mathrm{CO}_{2}$ concentration via air perturbation continuously pumped at high flow $(\sim 25$ $1 / \mathrm{min}$ ) through a sparger located at the bottom of the barrel to ensure rapid air-sea $p \mathrm{CO}_{2}$ equilibration. Air from the four treatment barrels was sequentially sampled and analyzed for $\mathrm{xCO}_{2}$. Measurements of $\mathrm{xCO}_{2}$ (in $\mathrm{ppm}$ ) were converted to $p \mathrm{CO}_{2}$ (in $\mu \mathrm{atm}$ ) by accounting for average hydrostatic pressure after bubble injection, water temperature and salinity and the humidity of the measurement gas stream following Dickson et al. (2007). Additionally, a zero-standard and ambient air were regularly measured to allow approximate drift-free operation. The measured $p \mathrm{CO}_{2}$ levels were compared by a central computer system to set points and adjusted by either (i) injecting small amount of pure $\mathrm{CO}_{2}$ into the circulated headspace air or (ii) recirculating the air through large soda lime-filled $\mathrm{CO}_{2}$ cartridges to remove $\mathrm{CO}_{2}$. The system allowed treatment and delivery of $\sim 50$ liters of water per hour. The four treatments included a pre-industrial scenario (PI; $280 \mu \mathrm{atm})$, a present-day scenario (PD; $410 \mu \mathrm{atm})$, and two concentrations based on scenarios for potential future atmospheres predicted for 2100 (Solomon, 2007): one based on a 'reduced' $\mathrm{CO}_{2}$ emission scenario (RE; $750 \mu \mathrm{atm}$ ) and one based on a 'business-as-usual' $\mathrm{CO}_{2}$ emission scenario (BU; $1050 \mu \mathrm{atm})$. Reported $p \mathrm{CO}_{2}$ is valid for the culturing temperature (i.e., slightly cooler than the treatment barrels), and estimated to be accurate to within $10 \mu \mathrm{atm}$.

Different amounts of dissolved organic and inorganic material were supplied from stock solutions by two 12-channel peristaltic pumps. Roswell Park Memorial Institute (RPMI) 1640 medium was used as the eutrophication supplement. RPMI is a wellknown culture medium and it has been used as a growth enhancer on C. crambe sponge explants (Camacho et al., 2006). It contains sugars, inorganic salts, amino acids and vitamins and was used to simulate different levels of eutrophication in the aquaria.

The experiment aimed to provide multiples $(1 \mathrm{x}, 2 \mathrm{x}, 3 \mathrm{x})$ of the natural near-shore labile DOC concentrations. Labile DOC represents the portion of the total DOC pool on which sponges can feed, here $\sim 20 \%$ of $\sim 80 \mu \mathrm{molC} / \mathrm{kg}$ (Van Duyl and Gast, 2001; De Goeij and Van Duyl, 2007). Treatments were E1: control labile DOC conditions (i.e., only $\sim 16 \mu \mathrm{mol} / \mathrm{kg}$ natural labile DOC), E2: double labile DOC conditions (natural DOC $+16 \mu \mathrm{mol} / \mathrm{kg}$ DOC as RPMI1640) and E3: triple labile DOC conditions (natural + 32 $\mu \mathrm{mol} / \mathrm{kg}$ RPMI 1640).

In total, 72 sponge-bearing cores and 24 control cores were collected and distributed evenly over the 12 scenarios, resulting in 2 sponge-bearing cores per aquarium and 2 control cores per scenario. Cores from increased- $p \mathrm{CO}_{2}$ scenarios were exposed to gradually increasing $p \mathrm{CO}_{2}$ over 1 week, ending with the desired $p \mathrm{CO}_{2}$ for that treatment. Addition of RPMI started as scenarios reached their desired $p \mathrm{CO}_{2}$ concentration. Subsequently, sponges were left to acclimatize to their respective carbon dioxide and eutrophication levels for a week prior to the incubations. Cores were placed in closed $0.5 \mathrm{~L}$ polycarbonate incubators with inbuilt stirrers in their respective aquaria to keep at constant temperature. Each incubation contained two cores and lasted $6 \mathrm{~h}$ to determine chemical bioerosion rates (see Assessment of Bioerosion Rates). The optimum incubation time was determined through trials of 2, 4, 6, and $8 \mathrm{~h}$. Although $6 \mathrm{~h}$ was considered the best fit to capture the alkalinity gradient caused by chemical bioerosion, it must be noted that sponges placed in 0.5 $\mathrm{L}$ of standing water for more than $1 \mathrm{~h}$ would experience lack of food and reduced amounts of oxygen (especially at night) over time. At the end of each incubation, cores were returned to their aquaria.

\section{Data Collection}

Temperature and irradiance of the water in the aquaria were recorded every $10 \mathrm{~min}$ by $6 \mathrm{HOBO}^{\circledR}$ Pendant UA-002-64 light and temperature loggers and 2 calibrated Odyssey PAR sensors (Dataflow Systems, X, Y), respectively. Salinity was recorded daily in each aquarium using a salinometer (VWR CO310). Oxygen was recorded using a PreSens $\mathrm{O}_{2}$ sensor (Fibox 4, PSt3) after each incubation. Throughout the experiment, every other day around noon, water samples were taken from each treatment to monitor carbonate chemistry, DOC and nutrients. Samples for alkalinity $\left(\mathrm{A}_{\mathrm{T}}\right)$ and dissolved inorganic carbon (DIC) were collected into $250 \mathrm{ml}$ borosilicate bottles and poisoned with $50 \%$ saturated $\mathrm{HgCl}_{2}$ solution (final concentration $0.02 \%$ ) to arrest biological activity. DOC samples $(30 \mathrm{ml})$ were collected in pre-combusted $\left(550^{\circ} \mathrm{C}\right)$ glass vials and acidified with 10 drops of concentrated $\mathrm{HCl}(37 \%)$. Both $\mathrm{A}_{\mathrm{T}}$ and DIC were measured on a Versatile Instrument for the Determination of Titration Alkalinity (VINDTA) model 3C (Marianda GmbH, Kiel, Germany). Determination of $\mathrm{A}_{\mathrm{T}}$ was by "open cell" potentiometric acid titration (Mintrop et al., 2000; Dickson 


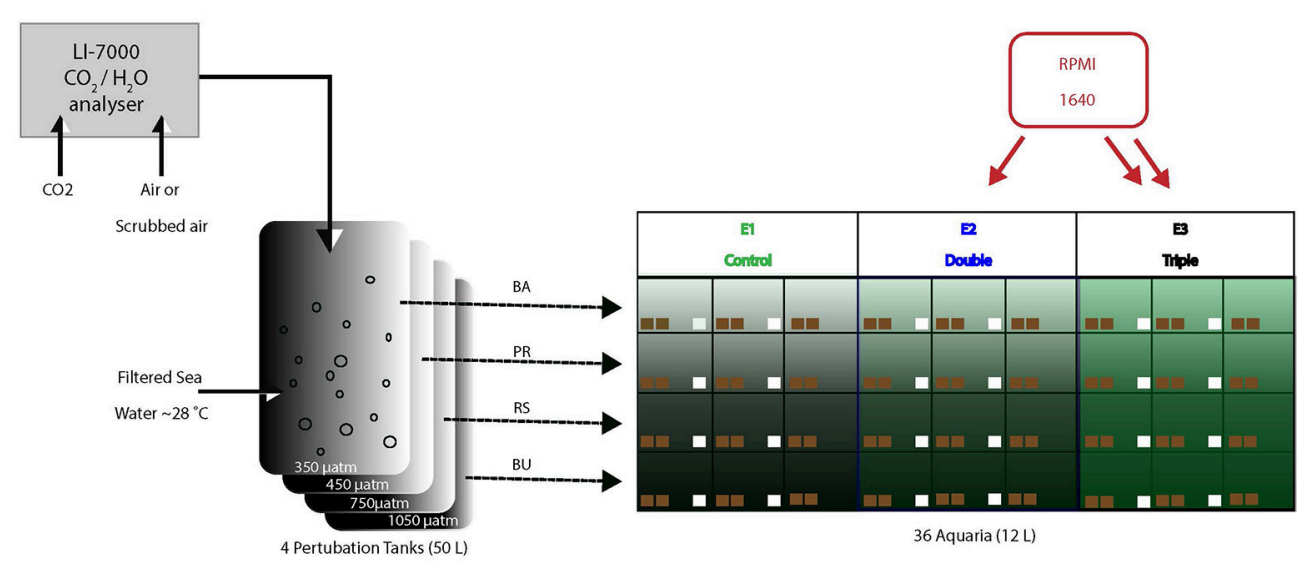

FIGURE 1 | Experimental setup consisting of four large barrels in which the $\mathrm{pCO}_{2}$ (4 levels) is manipulated and controlled through a central $\mathrm{CO}_{2}$ sensor. From every barrel, water is pumped into 9 aquaria (12 L each). Of these 9, two groups of 3 aquaria were supplied with additional dissolved organic carbon (E1: green, E2: blue, E3: black) using peristaltic pumps. Pumps ran at different speed between E2 and E3 to deliver different concentration of RPMl. Each of the 36 aquaria contained 2 sponge bearing coral cores (brown squares) and 24 aquaria contained control cores (white squares).

et al., 2007) and DIC was measured coulometrically (Johnson et al., 1993; Dickson et al., 2007). Prevention of drift and a high accuracy for $\mathrm{A}_{\mathrm{T}}$ and DIC were attained by analysis of certified reference material (CRM; supplied by Dr. A. Dickson, Scripps Institution of Oceanography) after every $\sim 20$ samples. The full carbonate system state was calculated from the measured temperature, salinity, $\mathrm{A}_{\mathrm{T}}$ and DIC using the Seacarb package (R-3.2.0) and using the dissociations constants preferred by Dickson and Millero (1987). Samples for determination of nitrate + nitrite, nitrite, phosphate and ammonium were filtered upon collection and stored frozen. Analyses for nutrients were carried out on a QuAAtro continuous flow analyzer (SEAL Analytical, GmbH, Norderstedt, Germany) following GO-SHIP protocol (Hydes et al., 2010). DOC analyses were performed with a total carbon analyzer (TOC-VPN, Shimadzu Corp., Kyoto, Japan).

\section{Assessment of Net Respiration and Photosynthesis Rates}

Observed changes in DIC and $\mathrm{A}_{\mathrm{T}}$ are governed by the combination of respiration and carbonate dissolution and the associated reverse processes of photosynthesis and calcification. The individual contributions of respiration and carbonate dissolution can be disentangled by empirically adjusting observed $\Delta \mathrm{A}_{\mathrm{T}}$ for nutrient effects using the measured nutrient concentration buildup. Indeed, in the case of incubation experiments, all of the change in nutrient concentrations must originate from processes within the incubation chamber. Therefore, this method will result in an appropriate estimate of respiration/dissolution, making calculated bioerosion rates insensitive to errors in measured DIC. Additionally, it takes into account the effect of release of $\mathrm{NH}_{4}^{+}$on measured $\mathrm{A}_{\mathrm{T}}$, which the vector deconvolution does not and cannot, due to the variable release stoichiometry of $\mathrm{NH}_{4}^{+}$. Calculations were carried out as follow:
Pretreatment:

$\Delta \mathrm{A}_{\mathrm{T}}^{\text {nutsreleasecorrected }}=\Delta \mathrm{A}_{\mathrm{T}}^{\text {obs }}+\Delta \mathrm{PO}_{4}+\Delta\left(\mathrm{NO}_{3}+\mathrm{NO}_{2}\right)-\Delta \mathrm{NH}_{4}$

Relationships:

$$
\begin{aligned}
& \Delta \mathrm{A}_{\mathrm{T}}^{\text {nutsreleasecorrected }}=2^{*} \text { diss } \\
& \Delta \mathrm{DIC}^{\text {obs }}=1^{*} \text { diss }+1^{*} \text { resp }
\end{aligned}
$$

$$
\begin{array}{ll}
\Delta \mathrm{A}_{\mathrm{T}}^{\text {resp }}=0 & \text { change in } \mathrm{A}_{\mathrm{T}} \text { due to respiration } \\
\Delta \mathrm{A}_{\mathrm{T}}^{\text {diss }}=\Delta A_{\mathrm{T}}^{\text {obs }} & \text { change in } \mathrm{A}_{\mathrm{T}} \text { due to dissolution } \\
\Delta \mathrm{DIC} \mathrm{C}^{\text {resp }}=\left(\Delta \mathrm{DIC}^{\text {obs }}-\mathrm{DIC}^{\text {diss }}\right) \text { change in DIC due to respiration } \\
\Delta \mathrm{DIC}^{\text {diss }}=\Delta \mathrm{A}_{\mathrm{T}}^{\text {obs }} / \mathrm{DIC}^{\text {diss }} & \text { change in DIC due to dissolution }
\end{array}
$$

$\Delta \mathrm{DIC}^{\mathrm{resp}}$ was then converted into respiration rates which were used to estimate approximately gross photosynthesis rates as follow:

$$
\mathrm{P}_{\text {gross }}=\text { Dark Resp net }- \text { Day Resp net }
$$

This method assumes that sponge host respiration is constant during day and night and that symbionts produce 1 mole of $\mathrm{O}_{2}$ for every mole of $\mathrm{CO}_{2}$ they fix.

\section{Assessment of Bioerosion Rates}

Total, chemical and mechanical bioerosion rates were quantified. Total bioerosion refers to the sum of both mechanical and chemical bioerosion.

We expressed chemical and mechanical rates both in $\mathrm{mg} \mathrm{cm}^{-2}$ $\mathrm{h}^{-1}$ (to distinguish rates between day and night) and in $\mathrm{mg}$ $\mathrm{cm}^{-2}$ day $^{-1}$ (sum of day and night rates). Total bioerosion was expressed in $\mathrm{mg} \mathrm{cm}^{-2} \mathrm{day}^{-1}$ using both buoyant weight results and the sum of day and night results for chemical and mechanical bioerosion.

\section{Chemical Bioerosion}

Chemical bioerosion was determined using the alkalinity anomaly technique (Smith and Key, 1975; Chisholm and 


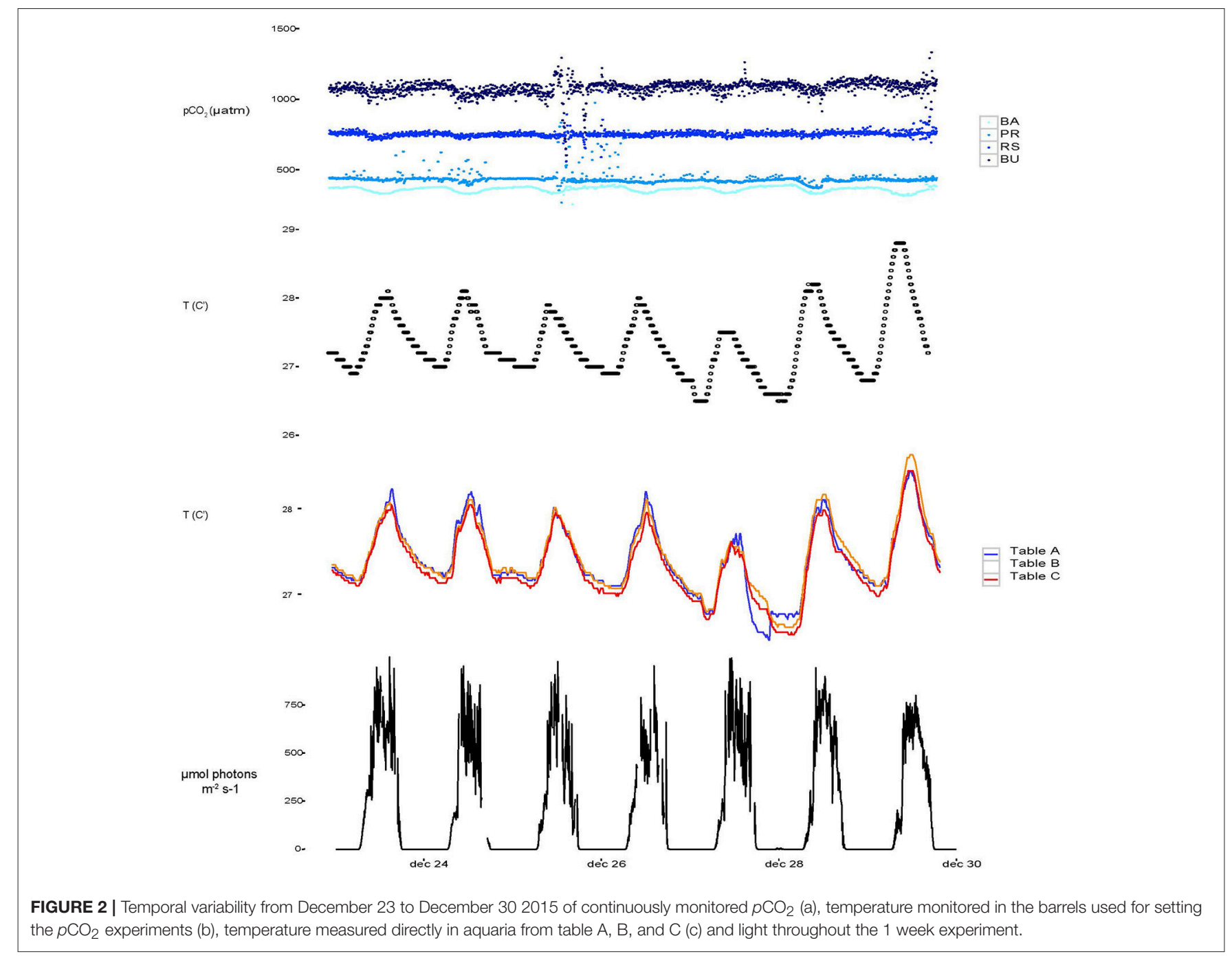

Gattuso, 1991) involving measured changes in $A_{T}\left(\mu \mathrm{mol} \mathrm{kg}^{-1}\right)$ associated with dissolution in seawater during $6 \mathrm{~h}$ incubation periods and correcting for changes in the concentrations of ammonium, nitrate and phosphate (Jacques and Pilson, 1980; Wisshak et al., 2013). The amount of mass of dissolved calcium carbonate $\left[\Delta M_{(\mathrm{CaCO} 3)}\right.$, in $\left.\mu \mathrm{g}\right]$ was calculated using Equation (1) (Zundelevich et al., 2007; Nava and Carballo, 2008):

$$
\begin{aligned}
\Delta M_{(\mathrm{CaCO} 3)}= & 0.5\left(\mathrm{~mol} \mathrm{eq}^{-1}\right) \times\left[\Delta \mathrm{A}_{\mathrm{T}}+\Delta \mathrm{PO}_{4}-\Delta \mathrm{NH}_{4}\right. \\
& \left.+\Delta\left(\mathrm{NO}_{3}+\mathrm{NO}_{2}\right)\right] \times \mathrm{V}_{\mathrm{SW}} \times \rho_{\mathrm{SW}} \times 100
\end{aligned}
$$

Where $\Delta \mathrm{A}_{\mathrm{T}}$ is the increase in $\mathrm{A}_{\mathrm{T}}$ over the incubation period associated with dissolution, $V_{S W}$ is the volume (l) of seawater in the incubation chamber and $\rho_{S W}$ is local seawater density $\left(1.022 \mathrm{~kg} \mathrm{~L}^{-1}\right)$. The multiplication factor " 100 " represents the molecular mass of $\mathrm{CaCO}_{3}$.

The $6 \mathrm{~h}$ incubations were carried out during both the day and at night, starting either $2 \mathrm{~h}$ after sunrise and $1 \mathrm{~h}$ after sunset, respectively. Subsamples were used for determination of $A_{T}$ and DIC ( $250 \mathrm{ml}$, single sample), DOC $(30 \mathrm{ml})$ and nutrient
$(5 \mathrm{ml})$ analysis from each chamber at the start and end of each incubation.

Bioerosion rates are commonly expressed as mass of removed substrate per unit surface area of the removing organism per unit time. Rates were therefore converted to $\mathrm{mg} \mathrm{cm}^{-2} \mathrm{~h}^{-1}$ by expressing the change in $\mathrm{A}_{\mathrm{T}}$ per surface area of the sponge. Two surface areas of the sponge-bearing cores were determined, the upper circle and the healed surface around the sides of the core.

\section{Mechanical Bioerosion}

Mechanical bioerosion was estimated by quantifying the $\mathrm{CaCO}_{3}$ sediment produced by $C$. caribbaea during $6 \mathrm{~h}$ incubations using the method described in Fang et al. (2013b). All remaining incubation chamber seawater $(\sim 150 \mathrm{ml})+$ sediment was collected and the chamber was rinsed with $100 \mathrm{ml}$ water to retrieve any remaining chips. The water was then sieved over a $150 \mu \mathrm{m}$ mesh to remove non-chip material and then filtered through a precombusted $\left(550^{\circ} \mathrm{C}, 3 \mathrm{~h}\right)$ and pre-weighed $\mathrm{GF} / \mathrm{F}$ glass microfiber filter $(0.7 \mu \mathrm{m}$; Whatman). Filters were then combusted at $550^{\circ} \mathrm{C}$ for $3 \mathrm{~h}$ to remove any organic matter and 
re-weighed to determine the difference in weight and hence that of the sediment produced.

\section{Total Bioerosion}

Total bioerosion (both mechanical and chemical) was estimated by the change in buoyant weight of the cores over the week of exposure to different $p \mathrm{CO}_{2}$ and eutrophication scenarios (Fang et al., 2013b). This method assumes organic components of the sponge to have a density equal to that of the ambient seawater (i.e., growth of the sponge will not change buoyant weight of the core). Both sponge cores and control cores were buoyant weighed using electronic scales with $0.1 \mathrm{mg}$ accuracy before and after the week's exposure to the various $p \mathrm{CO}_{2}$ levels. The buoyant mass change of the cores was calibrated for seawater density and corrected by the change in buoyant weight of the control cores, which integrated possible dissolution by other bioeroders, abrasion caused to handling process and accretion due to the potential presence of calcifying organisms.

\section{Statistical Analysis}

All statistical analysis were performed using the programming environment R 3.3.2 (R Core Team, 2013). Dependent variables acquired from incubation experiments were analyzed by means of an analysis of covariance (ANCOVA) with two categorical factors (Eutrophication, day/night) including three (E1, E2, and E3) and two (day and night) levels, respectively and one continuous covariate $\left(p \mathrm{CO}_{2}\right)$. Total bioerosion rates acquired from buoyant weight measurements and net photosynthesis rates were analyzed by means of a $4 \times 3$ crossed analysis of variance (ANOVA) with two categorical factors $\left(p \mathrm{CO}_{2}\right.$, eutrophication) including four (BA, PR, RS, and BU) and three (E1, E2, and E3) levels, respectively.

Normality and homoscedacity were confirmed using the Shapiro-Wilk and Levene's test, respectively. If no significant twoway interactions were revealed, main effects were reported. In the case of significant interactive effects, Post hoc tests (Tukey HSD with Bonferroni correction) were applied to determine the effect of a factor at each level of the other.

In addition, linear regression models were performed, after confirming assumptions for residual normality and homoscedacity, between $p \mathrm{CO}_{2}$ (now as a continuous predictor variable) and chemical bioerosion rates for each eutrophication and time levels.

\section{RESULTS}

\section{Health}

The sponge tissue damaged due to coring healed during the recovery session and started growing along the upper sides of the core throughout the experiment which indicated that sponges were healthy and recovering. Sponge color from the start to the end only varied very slightly, sponges in every treatment became a bit darker which may indicate a higher chlorophyll-a content in symbionts or an increase in symbiont abundance. Fluorescein injections revealed that sponges were still filtering half way through experiment.

\section{Seawater Variables}

Over the course of the experiment, headspace $p \mathrm{CO}_{2}$ in the four barrels remained sufficiently constant to warrant distinction between treatments (Figure 2, Table 1). Calculated mean $p \mathrm{CO}_{2}$ values in the experimental aquaria were 362.5, 443.8, 755.9, and $1046.0 \mu$ atm under PI, PD, RE, and $\mathrm{BU}$. The $p \mathrm{CO}_{2}$ levels in PI were on average $82.5 \mu$ atm higher than the intended pre-industrial $p \mathrm{CO}_{2}$ levels. However, they remained significantly different from the present scenario and therefore the pre-industrial scenario will be termed "Below-ambient" (BA) in the following text. Sponge cores were exposed to natural variations in temperature and light which, however, proved to be minimal over the experimental period. The average experimental temperature was $27.63^{\circ} \mathrm{C}\left(\min =25.81^{\circ} \mathrm{C}\right.$ and $\max =29.75^{\circ} \mathrm{C}$ ) and the average light intensity registered inside the aquaria around midday was $562 \pm 125.0 \mu \mathrm{mol}$ photons $\mathrm{m}^{-2} \mathrm{~s}^{-1}$. Measured DIC and hence all calculated carbonate system parameters were found to vary significantly across the four OA scenarios (Table 1) and dissolved organic carbon (DOC), ammonium (NH4), and phosphate $\left(\mathrm{PO}_{4}\right)$ concentrations were found to increase significantly across the eutrophication treatments (Table 2, Supplementary Figure S1).

Bioerosion, photosynthesis and respiration within incubations altered the carbonate chemistry of the water (Table 1). Within the holobiont microenvironment, photosynthesis would increase the local $\mathrm{pH}$ while respiration would increase local acidification. Throughout all incubations, the $p \mathrm{CO}_{2}$ concentrations increased and the $\mathrm{pH}$ and $\mathrm{O}_{\text {aragonite }}$ decreased. The change in $p \mathrm{CO}_{2}, \mathrm{pH}$ and $\mathrm{O}_{\text {aragonite was }}$ significantly different between $p \mathrm{CO}_{2}$ scenarios and between day and night. In none of the incubations, $\mathrm{O}_{\text {aragonite }}$ reached values below 1. Initial $p \mathrm{CO}_{2}$ concentrations calculated from $\mathrm{A}_{\mathrm{T}}$ and DIC at the beginning of each chamber incubation were found to increase slightly with addition of RPMI for each OA scenario. Accordingly, $\mathrm{pH}$ and $\mathrm{CaCO}_{3}$ saturation state decreased with addition of RPMI for each OA scenario. However, no significant difference was found in calculated $\mathrm{pCO}_{2}$ concentrations, $\mathrm{pH}$, and $\mathrm{CaCO}_{3}$ saturation state between eutrophication treatments in each OA scenario. Dissolved organic carbon and nutrient concentrations increased overall throughout incubations (Table 2, Supplementary Figure S2).

The observed increase in nutrients (Table 2) was not unexpected (Maldonado et al., 2012), but the enhanced concentrations could have interfered S2 with chemical bioerosion measurements. The increase in dissolved organic carbon (Table 2) was likely caused by the confinement of sponges in the incubation chambers, where sponge waste products were refiltered during the $6 \mathrm{~h}$ incubation. Nevertheless, Cliona delitrix, another clinoid sponge, is known to assimilate DOM, which comprises a large part of its diet (Mueller et al., 2014). Despite these confinement effects, relative differences in bioerosional processes between treatments were still observed.

\section{Chemical Bioerosion Rates}

In total, 72 chamber incubations were conducted (36 during the day and 36 at night) after 1 week exposure to treatments. Of all incubations, 13 were compromised due to technical 
TABLE 1 | Seawater physical and carbonate chemistry parameters at the start $\left(T_{0}\right)$ and the end $\left(T_{6}\right)$ of incubation experiments, averaged ( \pm standard deviation) over all incubations for each $\mathrm{pCO}_{2}$ scenario.

\begin{tabular}{|c|c|c|c|c|c|}
\hline & \multicolumn{2}{|c|}{ BA } & PD & RE & BU \\
\hline $\mathrm{T}_{\text {barrel }}\left[{ }^{\circ} \mathrm{C}\right]$ & \multicolumn{2}{|c|}{$27.33 \pm 0.48$} & $27.33 \pm 0.48$ & $27.33 \pm 0.48$ & $27.33 \pm 0.48$ \\
\hline Taquaria $\left[{ }^{\circ} \mathrm{C}\right]$ & \multicolumn{2}{|c|}{$27.69 \pm 0.02$} & $27.52 \pm 0.02$ & $27.61 \pm 0.03$ & $27.71 \pm 0.02$ \\
\hline Salinity & \multicolumn{2}{|c|}{$34.1 \pm 0.2$} & $34.1 \pm 0.2$ & $34.1 \pm 0.2$ & $34.1 \pm 0.2$ \\
\hline$p \mathrm{CO}_{2}^{\text {meas }}[\mu \mathrm{atm}]^{\star}$ & \multicolumn{2}{|c|}{$361.32 \pm 18.2$} & $436.61 \pm 74.60$ & $754.40 \pm 55.80$ & $1081.37 \pm 60.18$ \\
\hline \multirow[t]{2}{*}{$\% \mathrm{O}_{2}$} & $\mathrm{~T}_{0}$ & $21.1 \pm 1.0$ & $21.5 \pm 1.1$ & $21.3 \pm 1.1$ & $21.0 \pm 0.9$ \\
\hline & $\mathrm{T}_{6}$ & $10.1 \pm 6.4$ & $10.5 \pm 6.8$ & $11.2 \pm 7.9$ & $12.1 \pm 9.3$ \\
\hline \multirow[t]{2}{*}{$\mathrm{A}_{\mathrm{T}}\left[\mu \mathrm{mol} \mathrm{kg}{ }^{-1}\right]$} & $\mathrm{T}_{0}$ & $2326.01 \pm 13.69$ & $2323.91 \pm 29.88$ & $2328.94 \pm 7.78$ & $2323.74 \pm 15.15$ \\
\hline & $\mathrm{T}_{6}$ & $2365.72 \pm 34.35$ & $2366.12 \pm 26.67$ & $2679.18 \pm 11.49$ & $2418.02 \pm 15.40$ \\
\hline \multirow[t]{2}{*}{$\mathrm{DIC}\left[\mu \mathrm{mol} \mathrm{kg}{ }^{-1}\right]^{*}$} & $\mathrm{~T}_{0}$ & $1979.17 \pm 44.13$ & $2018.88 \pm 34.68$ & $2129.06 \pm 32.46$ & $2176.57 \pm 33.91$ \\
\hline & $\mathrm{T}_{6}$ & $2075.53 \pm 51.40$ & $2099.46 \pm 50.66$ & $2264.39 \pm 37.47$ & $2337.77 \pm 48.80$ \\
\hline \multirow[t]{2}{*}{$p \mathrm{CO}_{2}^{\text {meas }}[\mu \mathrm{atm}]^{\star}$} & $\mathrm{T}_{0}$ & $362.51 \pm 72.94$ & $443.82 \pm 110.20$ & $755.87 \pm 149.43$ & $1046.02 \pm 270.69$ \\
\hline & $\mathrm{T}_{6}$ & $490.49 \pm 105.19$ & $559.18 \pm 132.49$ & $1313.25 \pm 285.40$ & $1640.54 \pm 335.66$ \\
\hline \multirow[t]{2}{*}{$\mathrm{pH}^{\text {calc }}$ (total scale) * } & $\mathrm{T}_{0}$ & $8.1 \pm 0.07$ & $8.0 \pm 0.08$ & $7.8 \pm 0.07$ & $7.69 \pm 0.10$ \\
\hline & $\mathrm{T}_{6}$ & $7.98 \pm 0.07$ & $7.93 \pm 0.09$ & $7.61 \pm 0.09$ & $7.52 \pm 0.10$ \\
\hline \multirow[t]{2}{*}{$\mathrm{HCO}_{3}^{- \text {calc }}\left[\mu \mathrm{mol} \mathrm{kg}{ }^{-1}\right]^{*}$} & $\mathrm{~T}_{0}$ & $1722.46 \pm 69.23$ & $1787.13 \pm 61.30$ & $1955.63 \pm 49.43$ & $2026.66 \pm 51.99$ \\
\hline & $\mathrm{T}_{6}$ & $1850.73 \pm 71.53$ & $1887.73 \pm 84.07$ & $2124.18 \pm 49.81$ & $2203.87 \pm 54.75$ \\
\hline \multirow[t]{2}{*}{$\mathrm{CO}_{3}^{2-\mathrm{calc}}\left[\mu \mathrm{mol} \mathrm{kg}{ }^{-1}\right]^{\star}$} & $\mathrm{T}_{0}$ & $247.06 \pm 27.99$ & $219.93 \pm 32.65$ & $153.3 \pm 21.24$ & $122.07 \pm 25.67$ \\
\hline & $\mathrm{T}_{6}$ & $211.75 \pm 28.10$ & $196.77 \pm 22.68$ & $105.26 \pm 11.73$ & $88.68 \pm 18.55$ \\
\hline \multirow[t]{2}{*}{$\Omega_{\text {aragonite }}$ calc * } & $\mathrm{T}_{0}$ & $4.00 \pm 0.45$ & $3.56 \pm 0.53$ & $2.49 \pm 0.35$ & $1.97 \pm 0.42$ \\
\hline & $\mathrm{T}_{6}$ & $3.43 \pm 0.46$ & $3.18 \pm 0.64$ & $1.70 \pm 0.33$ & $1.43 \pm 0.30$ \\
\hline \multirow[t]{2}{*}{$\Omega_{\text {calcite }}$ calc * } & $\mathrm{T}_{0}$ & $6.02 \pm 0.69$ & $5.36 \pm 0.80$ & $3.74 \pm 0.52$ & $2.98 \pm 0.63$ \\
\hline & $\mathrm{T}_{6}$ & $5.16 \pm 0.69$ & $4.80 \pm 0.96$ & $2.56 \pm 0.50$ & $2.16 \pm 0.46$ \\
\hline
\end{tabular}

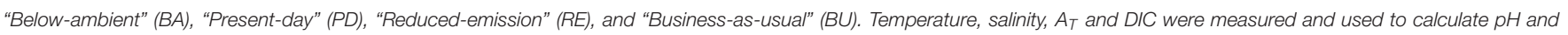

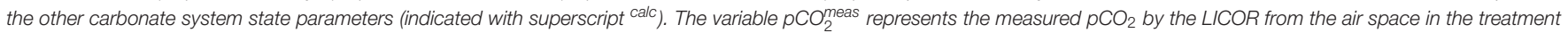

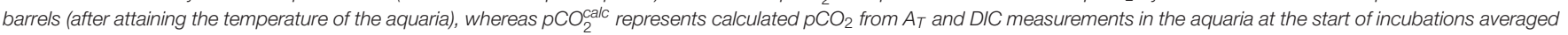
for each scenario.

"Significant difference across all OA scenarios marked with an asterix.

complications. The results for the successful 59 incubations are presented here. For the present-day (PD) $p \mathrm{CO}_{2}$ scenario, no data in treatment $\mathrm{E} 2$ during the day are available.

As sponges experienced significant increase in $p \mathrm{CO}_{2}$ concentrations throughout incubations, chemical rates were regressed against the average calculated $p \mathrm{CO}_{2}$ obtained from $\mathrm{A}_{T}$ and DIC measurement at the start and end of each incubations. As a result, for each $p \mathrm{CO}_{2}$ scenario, day and night $\mathrm{pCO}_{2}$ levels differ from each other.

Chemical bioerosion rates of $C$. caribbaea increased significantly with $\mathrm{pCO}_{2}$ and eutrophication levels but no interaction was found between the two effects (Figure 3, Tables 3, 5). In addition, day-time chemical bioerosion rates are shown to differ significantly from night-time rates, and an interaction between the effects of $p \mathrm{CO}_{2}$ and day-night is revealed (Tables 3, 4). A post hoc pairwise comparison revealed that the significant differences in chemical bioerosion rates between day and night mostly occurred at low $\mathrm{pCO}_{2}$ scenarios where day time rates were $\sim 50 \%$ higher than night-time rates. In high $p \mathrm{CO}_{2}$ scenarios ( $\mathrm{RE}$ and $\mathrm{BU}$ ), average day-time and night-time rates were equal in $\mathrm{E} 1$ and average night-time rates surpassed day-time ones in E2 and E3 (Table 3). The increase in $\mathrm{pCO}_{2}$ concentration during incubations at day and night was not significantly different between PD, RS, and BU. This indicates that the switch from higher rates during the day at low $p \mathrm{CO}_{2}$ scenarios (BA and PR) to equal/higher rates in $\mathrm{RE}$ and $\mathrm{BU}$ is not primarily linked to the difference in day and night $p \mathrm{CO}_{2}$.

Average day and night chemical bioerosion rates increased significantly from E1 to $\mathrm{E} 3$ for each of the $\mathrm{pCO}_{2}$ scenarios, however, increases in rates from $\mathrm{E} 1$ to $\mathrm{E} 2$ were minute and even negative at night (Table 3). Daily chemical rates (mg $\mathrm{cm}^{-2}$ day $^{-1}$ ) in BA, PR, RE, and BU increased by 80, 83, 20, and 53\% from E1 to E3, respectively (Table 4). Rates in E1 and E3 increased by 150 and 109\% respectively from current 
TABLE 2 | Initial $\left(T_{0}\right)$ and final $\left(T_{6}\right)$ DOC and nutrient concentrations averaged over all incubations ( \pm standard deviation) for the three "eutrophication" treatments: "E1" (natural organic loading), "E2" (double labile organic loading), "E3" (triple labile organic loading).

\begin{tabular}{ccccc}
\hline & & E1 & E2 & E3 \\
\hline $\mathrm{DOC}\left[\mu \mathrm{mol} \mathrm{kg}{ }^{-1}\right]^{\star}$ & $\mathrm{T}_{0}$ & $82 \pm 4$ & $96 \pm 4$ & $106 \pm 13$ \\
& $\mathrm{~T}_{6}$ & $106 \pm 12$ & $122 \pm 18$ & $123 \pm 19$ \\
\hline $\mathrm{NO}_{\times}\left[\mu \mathrm{mol} \mathrm{kg}{ }^{-1}\right]$ & $\mathrm{T}_{0}$ & $1.0 \pm 0.4$ & $1.0 \pm 0.5$ & $1.0 \pm 0.5$ \\
& $\mathrm{~T}_{6}$ & $1.1 \pm 0.5$ & $1.1 \pm 0.5$ & $1.3 \pm 0.7$ \\
\hline $\mathrm{NO}_{2}\left[\mu \mathrm{mol} \mathrm{kg}{ }^{-1}\right]$ & $\mathrm{T}_{0}$ & $0.1 \pm 0.04$ & $0.1 \pm 0.03$ & $0.2 \pm 0.1$ \\
& $\mathrm{~T}_{6}$ & $0.2 \pm 0.1$ & $0.2 \pm 0.1$ & $0.3 \pm 0.1$ \\
\hline $\mathrm{NH}_{4}\left[\mu \mathrm{mol} \mathrm{kg}{ }^{-1}\right]$ & $\mathrm{T}_{0}$ & $2.6 \pm 0.3$ & $3.4 \pm 2.8$ & $4.3 \pm 4.1$ \\
& $\mathrm{~T}_{6}$ & $19.4 \pm 12.1$ & $24.6 \pm 14.0$ & $25.3 \pm 11.8$ \\
\hline $\mathrm{PO}_{4}\left[\mu \mathrm{mol} \mathrm{kg}{ }^{-1}\right]^{\star}$ & $\mathrm{T}_{0}$ & $0.01 \pm 0.01$ & $1.4 \pm 0.9$ & $2.9 \pm 2.3$ \\
& $\mathrm{~T}_{6}$ & $0.5 \pm 0.5$ & $2.41 \pm 1.0$ & $4.0 \pm 2.5$ \\
\hline
\end{tabular}

*Significant difference across eutrophication scenarios marked with an asterix.

$p \mathrm{CO}_{2}$ levels to the $\mathrm{BU}$ scenario (no $\mathrm{PD}, \mathrm{E} 2$ chemical rate available).

In these calculations, abiotic dissolution was assumed negligible as aragonite saturation states always remained above 1. Possible bioerosion by other organisms living in the cores is not accounted for in our calculations but is considered minimal throughout the incubation period due to very low $\mathrm{A}_{\mathrm{T}}$ changes in control core incubations (Supplementary Table S1).

\section{Mechanical and Total Bioerosion Rates}

Mechanical bioerosion estimated from chip collection was not significantly different between $\mathrm{PCO}_{2}$ scenarios and eutrophication treatments and no interaction was found between effects (Tables 4,5 ). The average hourly mechanical erosion rate for all $p \mathrm{CO}_{2}$ scenarios and eutrophication treatments during day and night equaled $0.02 \pm 0.01 \mathrm{mg} \mathrm{cm}^{-2} \mathrm{~h}^{-1}$. The average daily rate estimated from the addition of night and day rates equaled to $0.40 \pm 0.11 \mathrm{mg} \mathrm{cm}^{-2} \mathrm{~d}^{-1}$.

The change in buoyant weight yielded average net bioerosion rates of $2.47 \pm 0.16,2.63 \pm 0.25,2.96 \pm 0.33$, and 3.34 $\pm 0.26 \mathrm{mg} \mathrm{cm}^{-2} \mathrm{~d}^{-1}$ for $\mathrm{BA}, \mathrm{PD}, \mathrm{RE}$, and $\mathrm{BU}$, respectively and increased significantly with $p \mathrm{CO}_{2}(p=0.009$; Figure 4, Table 5). Although in most $p \mathrm{CO}_{2}$ scenarios, treatment $\mathrm{E} 2$ and E3 yielded higher total bioerosion rates than in E1, rates were not found to increase significantly with eutrophication (Figure 4, Table 5). Net bioerosion rates calculated from buoyant weight measurements were $\sim 4-5$ times higher than the sum of the measured chemical and mechanical (chips) bioerosion rates at day and night (Figures 4, 5, Table 4).

\section{Net Respiration and Photosynthetic Rates}

Net holobiont (sponge + symbionts) respiration showed antagonistic behavior between day and night as $p \mathrm{CO}_{2}$ increased. Net respiration during the day decreased with high $\mathrm{pCO}_{2}$ while net respiration at night increased (Figure 6). Rates were found to vary significantly between day and night $(p \leq 0.001)$ but not between $\mathrm{pCO}_{2}$ scenarios and eutrophication treatments. An interaction between factors day/night and $p \mathrm{CO}_{2}$ levels was revealed (Table 5).

Accordingly, photosynthesis rates $\left(\mathrm{O}_{2}\right.$ production), estimated from the difference between net respiration rates at day and night, increased significantly with increasing $p \mathrm{CO}_{2}(p=0.004$; Figure 6, Table 5). No significant difference was found between primary production and eutrophication scenarios, although photosynthetic activity appeared to decrease with increasing eutrophication in most $p \mathrm{CO}_{2}$ scenarios.

\section{DISCUSSION}

Total bioerosion rates by the common coral excavating sponge Cliona caribbaea are experimentally shown to increase with rising $\mathrm{pCO}_{2}$ (Figure 4), while the corresponding chemical bioerosion component increased significantly with both $\mathrm{pCO}_{2}$ and eutrophication (Figure 3). Mechanical bioerosion exceeded chemical bioerosion by 3-6 times irrespective of $\mathrm{pCO}_{2}$ and eutrophication. Contribution of eutrophication to higher chemical bioerosion rates was additive to $\mathrm{pCO}_{2}$ effects (i.e., not synergetic). Differences between day-time and nighttime chemical bioerosion rates at below-ambient and present $p \mathrm{CO}_{2}$ levels suggests that photosynthetic activity by symbionts promotes the dissolution process. While under rising $p \mathrm{CO}_{2}$, the symbiotic relationship appears to become negligible to the bioerosion activity as night-time rates equal/surpass day-time rates.

\section{Effects Of $\mathrm{pCO}_{2}$ and Eutrophication on Bioerosion}

Results regarding higher rates at increased $p \mathrm{CO}_{2}$ are comparable to previous studies on other clionaid species (C. orientalis and C. celata) (Wisshak et al., 2012, 2013, 2014; Fang et al., 2013a). Sponges and other borers are assumed to benefit from eutrophication (Holmes, 2000; Carballo et al., 2008). Many sponges on reefs harbor photosynthetic symbionts and in some cases they produce $>50 \%$ of the energy requirements of the host (Erwin and Thacker, 2008). They rely nevertheless also on organic matter for food and their feeding strategy may be flexible depending on the type of symbionts or the environmental conditions. To maintain a positive energy budget, C. caribbaea likely relies mainly on autotrophic products (Weisz et al., 2010; Fang et al., 2014) and thus depends on the supply of organic matter for maintenance and growth from its photosymbionts. Considering the low phosphate concentrations in $\mathrm{E} 1 \quad\left(\sim 0.01 \mu \mathrm{mol} \mathrm{l}^{-1}\right)$, primary production may have been limited by phosphate. However, the addition of RPMI and hence higher phosphate concentrations did not enhance photosynthetic activity from E1 to E3. On the contrary, in most $p \mathrm{CO}_{2}$ scenarios, net primary production estimates decreased slightly (nonsignificant) from E1 to E3, while sponge chemical bioerosion rates were enhanced. It should be noted here that potential light limitation of symbiont photosynthesis in the incubations tanks may not be discounted. Under increased organic matter 


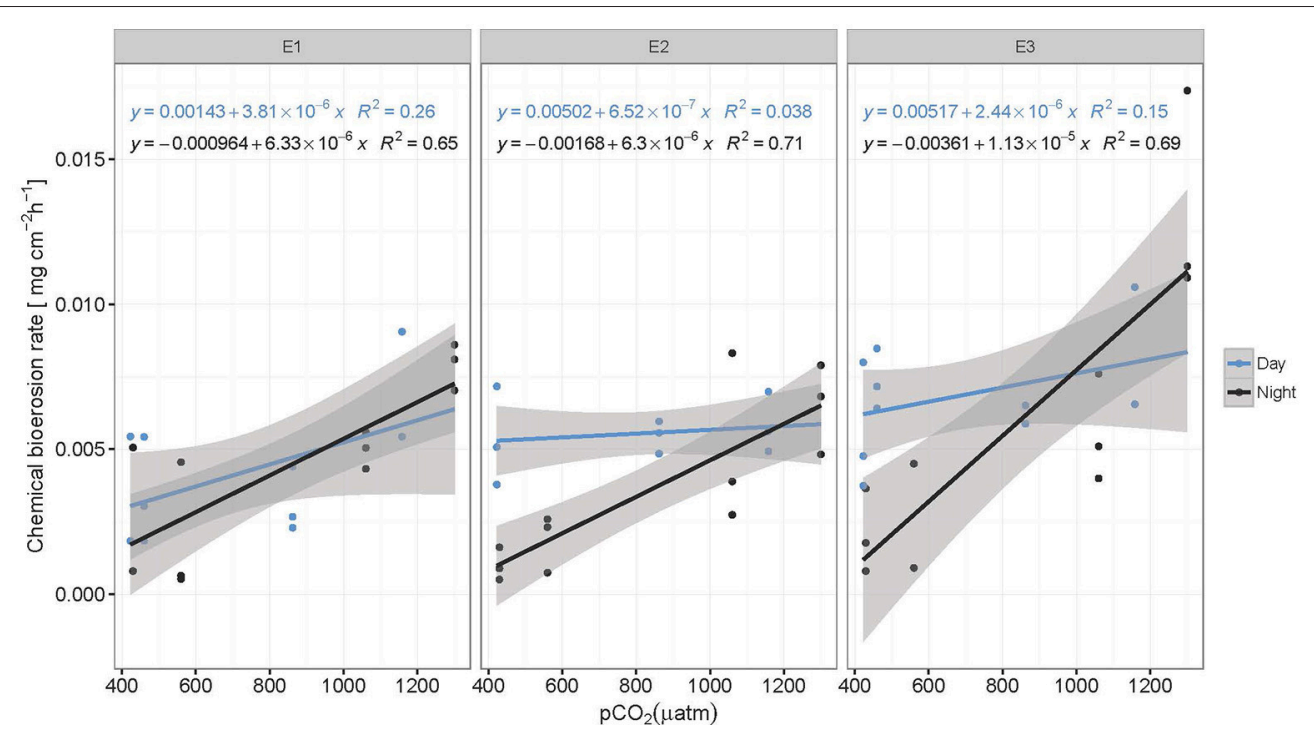

FIGURE 3 | Chemical bioerosion rates in $\mathrm{mg} \mathrm{cm}^{-2} \mathrm{~h}^{-1}$ as a function of $\mathrm{pCO}_{2}$ for day and night and each eutrophication treatment. Linear regressions illustrate positive correlation between pCO2 and dissolution rates. Slopes are significantly different between day (blue) and night (black) but not between eutrophication scenarios (E1-E3). Alkalinity titrations for incubations in Present scenario (PD) and E2 treatment during the day were of questionable quality due to equipment failure and therefore not represented here $(N=59)$.

and nutrient levels, the sponges may be less dependent on autotrophic products. However, as the increase in chemical bioerosion rates from E1 to E3 was more pronounced during the day (at low and ambient $p \mathrm{CO}_{2}$ levels), it is likely that the autotrophic/heterotrophic ratio of energy supply only shifts slightly toward heterotrophy and the sponges still rely partly on autotrophic products.

Chemical bioerosion rates at night-time increase also (at a lesser degree) with higher eutrophication, indicating that chemical bioerosion does indeed benefit from a higher energy supply via heterotrophic feeding. This implies that increased eutrophication did not impact the productivity of the symbionts. Sponges, like corals, can exercise control on symbiont growth and abundance by inhibiting division or ingesting them to maintain population size near a carrying capacity (Hill, 2014).

Total bioerosion rates calculated using buoyant weight measurements were experimentally shown to increase significantly with $\mathrm{pCO}_{2}$ but not with eutrophication. These results are unexpected considering the significant impact eutrophication has on chemical bioerosion. However, the relatively short term experiment coupled with the smaller effect of eutrophication on chemical rates compared to the $p \mathrm{CO}_{2}$ impact may have obscured this signal.

Total bioerosion rates estimated from buoyant weights resulted in $\sim 5$ times higher rates than those based on the sum of chip production and the change in $A_{T}$ (Figures 4, 5). This is comparable to results from Fang et al. (2013a) and may be explained by an underestimation of the chip removal capacity of the sponge. Rates calculated using buoyant weight measurements are based on a longer period of bioerosion ( 1 week), whereas the chip removal is based on their collection at the end of a relatively short incubation period
TABLE 3 | Averages ( \pm standard deviation) of chemical bioerosion rates in $\mathrm{mg}$ $\mathrm{cm}^{-2} \mathrm{~h}^{-1}$, as calculated from change in $A_{T}$ during incubations.

$\left.\begin{array}{ccccc}\hline & & \text { E1 } & \text { E2 } & \text { E3 } \\ \hline \text { BA } & \text { Day } & 0.004 \pm 0.003 & 0.005 \pm 0.002 & 0.006 \pm 0.002 \\ & \text { Night } & 0.003 \pm 0.003 & 0.001 \pm 0.001 & 0.002 \pm 0.001 \\ \text { PR } & \text { Day } & 0.004 \pm 0.002 & x & 0.007 \pm 0.001 \\ & \text { Night } & 0.002 \pm 0.002 & 0.002 \pm 0.001 & 0.003 \pm 0.003\end{array}\right\}$ A

Values are provided for in each $O A$ scenario, eutrophication treatment, and light regime. In $B A$ and PR scenarios (A), day-time rates are generally more than $\sim 50 \%$ higher than night-time rates. In RE scenario $(B)$, day-time and night-time rates are roughly similar, while in $B U(C)$ night-time rates surpass day-time rates in the in all eutrophication treatments.

(6h). Sponges might expel chips irregularly or they may temporarily reduce chip removal during incubations possibly due to stress caused by reduced food supply or build-up of waste products, both of which may become important toward the end of the $6 \mathrm{~h}$-incubation period. Therefore, the sum of chemical and mechanical bioerosion should be considered as being conservative. Here, total bioerosion rates yielded from buoyant weight measurements are regarded as more reliable and are comparable to results estimated from previous studies (Fang et al., 2013a; Wisshak et al., 2013).

Rates of chip production did not differ significantly between $p \mathrm{CO}_{2}$ scenarios, day/night and eutrophication treatments. 
TABLE 4 | Daily averages ( \pm standard deviation) of total, mechanical, and chemical bioerosion rates in $\mathrm{mg} \mathrm{cm}^{-2} \mathrm{~d}^{-1}$.

\begin{tabular}{llccc}
\hline & & E1 & E2 & E3 \\
\hline BA & Total BW & $2.21 \pm 0.61$ & $2.53 \pm 0.61$ & $2.55 \pm 0.59$ \\
& Mechanical & $0.23 \pm 0.03$ & $0.51 \pm 0.15$ & $0.38 \pm 0.08$ \\
& Chemical & $0.05 \pm 0.02$ & $0.08 \pm 0.01$ & $0.09 \pm 0.04$ \\
\hline PR & Total BW & $2.81 \pm 0.98$ & $2.05 \pm 0.20$ & $2.84 \pm 1.12$ \\
& Mechanical & $0.40 \pm 0.09$ & $0.31 \pm 0.07$ & $0.39 \pm 0.13$ \\
& Chemical & $0.06 \pm 0.02$ & $\times$ & $0.11 \pm 0.04$ \\
\hline RS & Total BW & $2.61 \pm 1.01$ & $2.94 \pm 1.47$ & $3.39 \pm 1.40$ \\
& Mechanical & $0.50 \pm 0.17$ & $0.33 \pm 0.09$ & $0.40 \pm 0.13$ \\
& Chemical & $0.10 \pm 0.02$ & $0.13 \pm 0.03$ & $0.12 \pm 0.05$ \\
\hline BU & Total BW & $3.08 \pm 0.66$ & $4.19 \pm 1.04$ & $2.76 \pm 0.45$ \\
& Mechanical & $0.23 \pm 0.07$ & $0.43 \pm 0.18$ & $0.59 \pm 0.22$ \\
& Chemical & $0.15 \pm 0.06$ & $0.15 \pm 0.02$ & $0.23 \pm 0.08$
\end{tabular}

Values are provided for each $O A$ scenario and eutrophication treatment. Daily total bioerosion rates are calculated using buoyant weight measurements. Daily mechanical and chemical bioerosion rates are the sum of hourly day and night rates, each multiplied by 12

Although the underlying method by which sponges expel chips is largely unknown, it appears that chips are expelled from the sponge body through excurrent canals (Rützler and Rieger, 1973). It is likely that chip removal processes utilize products from the dissolution to contract their tissue and move the chip up from the boring pit into an excurrent canal. Work on phototrophic cyanobacteria showed that microbial excavation was achieved by transcellular $\mathrm{Ca}^{2+}$ transport (Garcia-Pichel, 2006; GarciaPichel et al., 2010; Guida and Garcia-Pichel, 2016). We tentatively suggest that the excess in $\mathrm{Ca}^{2+}$ derived from the dissolution in $\mathrm{CaCO}_{3}^{-}$may be used by sponges to contract a conductive pathway, similarly to how muscle cell contract when triggered by an increase in intracellular $\mathrm{Ca}^{2+}$ (Sommerville and Hartshorne, 1986).

\section{Respiration, Photosynthesis and Changes in Chemical Bioerosion Rates}

Changes in chemical bioerosion activity can be associated with three processes within the holobiont: $\mathrm{CO}_{2}$ fixation/respiration by the symbionts, respiration by the sponge and chemical bioerosion. Photosynthesis promotes chemical bioerosion rates during the day at low $\mathrm{pCO}_{2}$ levels (BA and PD) (Figure 3, Table 3). Differences in rates between day and night are comparable to results from previous studies where C. orientalis and $C$. varians (both symbiont bearing species) excavated with higher rates in day light compared to the dark or shade at ambient $p \mathrm{CO}_{2}$ (Hill, 1996; Schönberg, 2006; Fang et al., 2016). Recent work by Fang et al. (2016) on the ecophysiology of C. orientalis showed that bioerosion rates in this sponge during day-time were $\sim 40 \%$ higher than in the dark. C. celata on the other hand, an azooxanthellate sponge, displayed no diurnal variability in bioerosion pattern (Schönberg, 2008). Based on
TABLE 5 | Three-way ANCOVAs, with bioerosion rates (chemical: $A_{T}$ change, mechanical: chip production, and total: buoyant weight) and net respiration rates as dependent factors, eutrophication, and day/night as independent categorical factors and $\mathrm{pCO}_{2}$ as a continuous covariable.

\begin{tabular}{|c|c|c|c|c|c|}
\hline Rates & df & ss & MS & $F$-value & $P$-value \\
\hline \multicolumn{6}{|c|}{ CHEMICAL BIOEROSION RATES } \\
\hline $\mathrm{pCO}_{2}$ & 2 & $2.1 \mathrm{e}-04$ & $2.1 e-04$ & 31.19 & $<0.001$ \\
\hline Eutro & 2 & $6.0 \mathrm{e}-05$ & $3.0 e-05$ & 3.32 & 0.04 \\
\hline day/night & 1 & $8.9 \mathrm{e}-06$ & $8.9 e-06$ & 0.91 & 0.34 \\
\hline $\mathrm{pCO}_{2}$ : Eutro & 2 & $1.4 \mathrm{e}-05$ & $7.2 \mathrm{e}-05$ & 1.77 & 0.18 \\
\hline $\mathrm{pCO}_{2}$ : day/night & 1 & $5.1 e-05$ & $5.1 e-05$ & 12.63 & $<0.001$ \\
\hline Eutro: day/night & 2 & $1.0 \mathrm{e}-05$ & $5.0 e-06$ & 1.24 & 0.30 \\
\hline $\mathrm{pCO}_{2}$ : Eutro: day/night & 2 & $1.1 \mathrm{e}-05$ & $5.3 e-06$ & 1.31 & 0.28 \\
\hline Residuals & 51 & $2.1 e-04$ & $4.1 \mathrm{e}-06$ & & \\
\hline \multicolumn{6}{|c|}{ MECHANICAL BIOEROSION RATES } \\
\hline $\mathrm{pCO}_{2}$ & 1 & $2.5 e-05$ & $2.5 e-05$ & 0.47 & 0.50 \\
\hline Eutro & 2 & 1.3 e-05 & $6.4 \mathrm{e}-06$ & 0.12 & 0.89 \\
\hline day/night & 1 & $1.9 \mathrm{e}-06$ & $1.9 e-06$ & 0.36 & 0.55 \\
\hline $\mathrm{pCO}_{2}$ : Eutro & 2 & $1.2 \mathrm{e}-04$ & $6.3 e-05$ & 1.18 & 0.33 \\
\hline $\mathrm{pCO}_{2}:$ day/night & 1 & $1.4 \mathrm{e}-04$ & $1.4 \mathrm{e}-04$ & 2.65 & 0.12 \\
\hline Eutro: day/night & 2 & $8.6 e-05$ & $4.3 e-05$ & 0.81 & 0.46 \\
\hline$p \mathrm{CO}_{2}$ : Eutro: day/night & 2 & $2.1 e-04$ & $1.1 e-04$ & 1.99 & 0.16 \\
\hline Residuals & 19 & $1.0 \mathrm{e}-03$ & $5.3 e-5$ & & \\
\hline \multicolumn{6}{|c|}{ TOTAL BIOEROSION RATES } \\
\hline $\mathrm{pCO}_{2}$ & 1 & 0.01 & 0.01 & 7.63 & 0.009 \\
\hline Eutro & 2 & 0.002 & 0.001 & 0.52 & 0.6 \\
\hline $\mathrm{pCO}_{2}$ : Eutro & 2 & 0.01 & 0.003 & 2.34 & 0.11 \\
\hline Residuals & 48 & 0.07 & 0.001 & & \\
\hline \multicolumn{6}{|c|}{ NET RESPIRATION RATES } \\
\hline $\mathrm{pCO}_{2}$ & 1 & 0.03 & 0.03 & 1.73 & 0.19 \\
\hline Eutro & 2 & 0.04 & 0.02 & 1.15 & 0.33 \\
\hline day/night & 1 & 0.50 & 0.50 & 28.13 & $<0.001$ \\
\hline $\mathrm{pCO}_{2}:$ Eutro & 2 & 0.001 & 0.001 & 0.04 & 0.96 \\
\hline $\mathrm{pCO}_{2}$ : day/night & 1 & 0.08 & 0.08 & 4.23 & 0.04 \\
\hline Eutro: day/night & 2 & 0.03 & 0.01 & 0.72 & 0.49 \\
\hline $\mathrm{pCO}_{2}$ : Eutro: day/night & 2 & 0.02 & 0.01 & 0.43 & 0.66 \\
\hline Residuals & 48 & 0.84 & 0.02 & & \\
\hline \multicolumn{6}{|c|}{ NET PHOTOSYNTHESIS RATES } \\
\hline $\mathrm{pCO}_{2}$ & 1 & 0.03 & 0.003 & 14.75 & 0.004 \\
\hline Eutro & 2 & 0.0004 & 0.0002 & 0.04 & 0.96 \\
\hline $\mathrm{pCO}_{2}$ : Eutro & 2 & 0.01 & 0.003 & 2.03 & 0.52 \\
\hline Residuals & 3 & 0.01 & 0.002 & & \\
\hline
\end{tabular}

Total bioerosion rates and net photosynthesis rates were analyzed using two-way ANOVAs with two categorical factors $\left(\mathrm{pCO}_{2}\right.$, eutrophication). Significant values in bold.

these findings, presence of Symbiodinium spp. was assumed to be associated with higher bioerosion rates (Hill, 1996; Fang et al., 2016). Geochemically speaking, this is a paradox because the autotrophic symbionts would tend to increase $\mathrm{pH}$, increase saturation state and thereby aid carbonate precipitation rather than its antagonistic process (Garcia-Pichel et al., 2010).

However, local acidification due to sponge respiration may balance out the increase in $\mathrm{pH}$ associated with photosynthesis. As symbionts do not produce a favorable environment for 


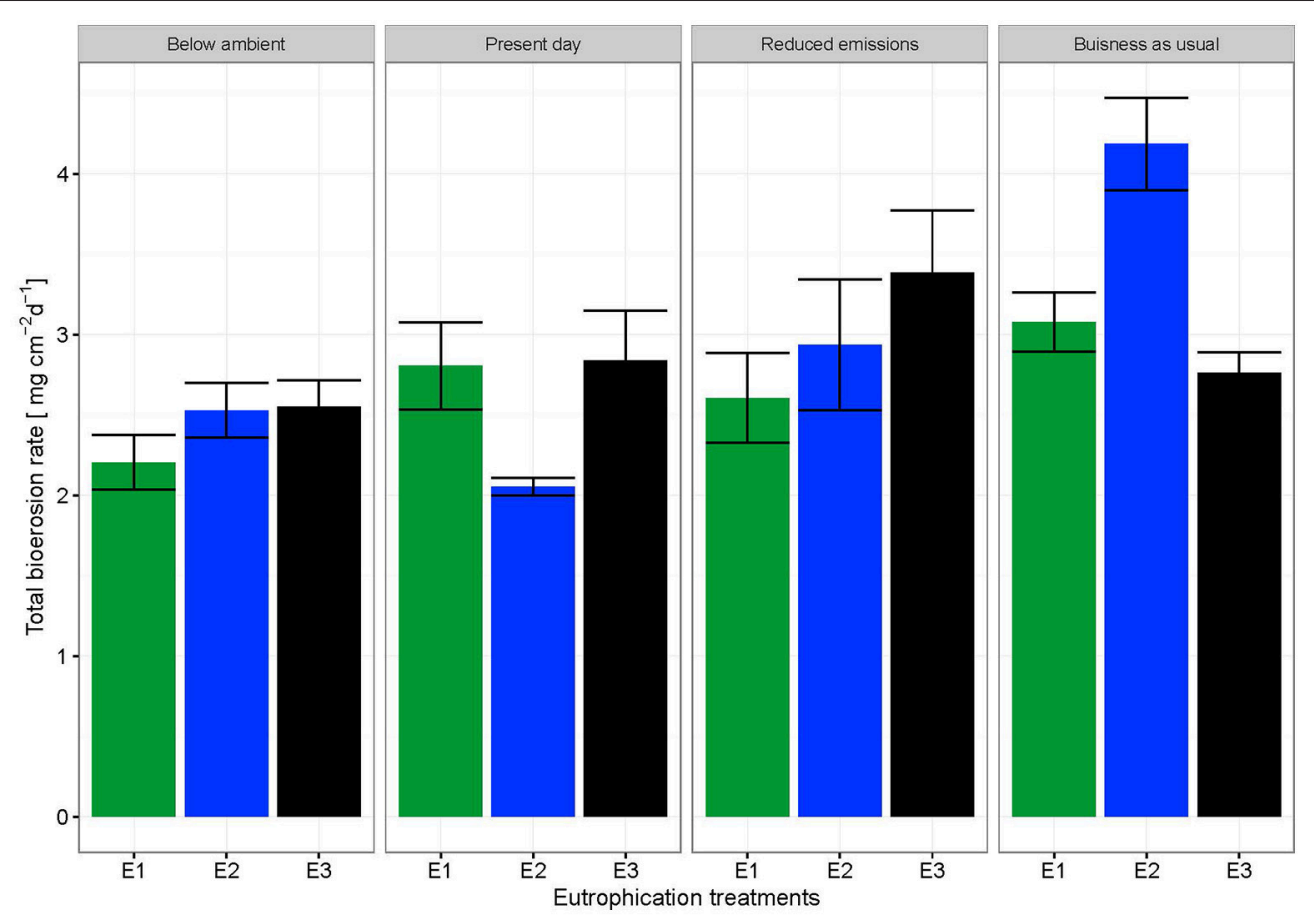

FIGURE 4 | Total bioerosion rates of $C$. caribbaea in $\mathrm{mg} \mathrm{cm}^{-2} \mathrm{~d}^{-1}$ estimated from buoyant weight measurements $\pm \mathrm{SEM}$ for each $p C \mathrm{O}_{2}$ and eutrophication scenario. Estimates for buoyant weighing are based on all individual measurements $(N=59)$.

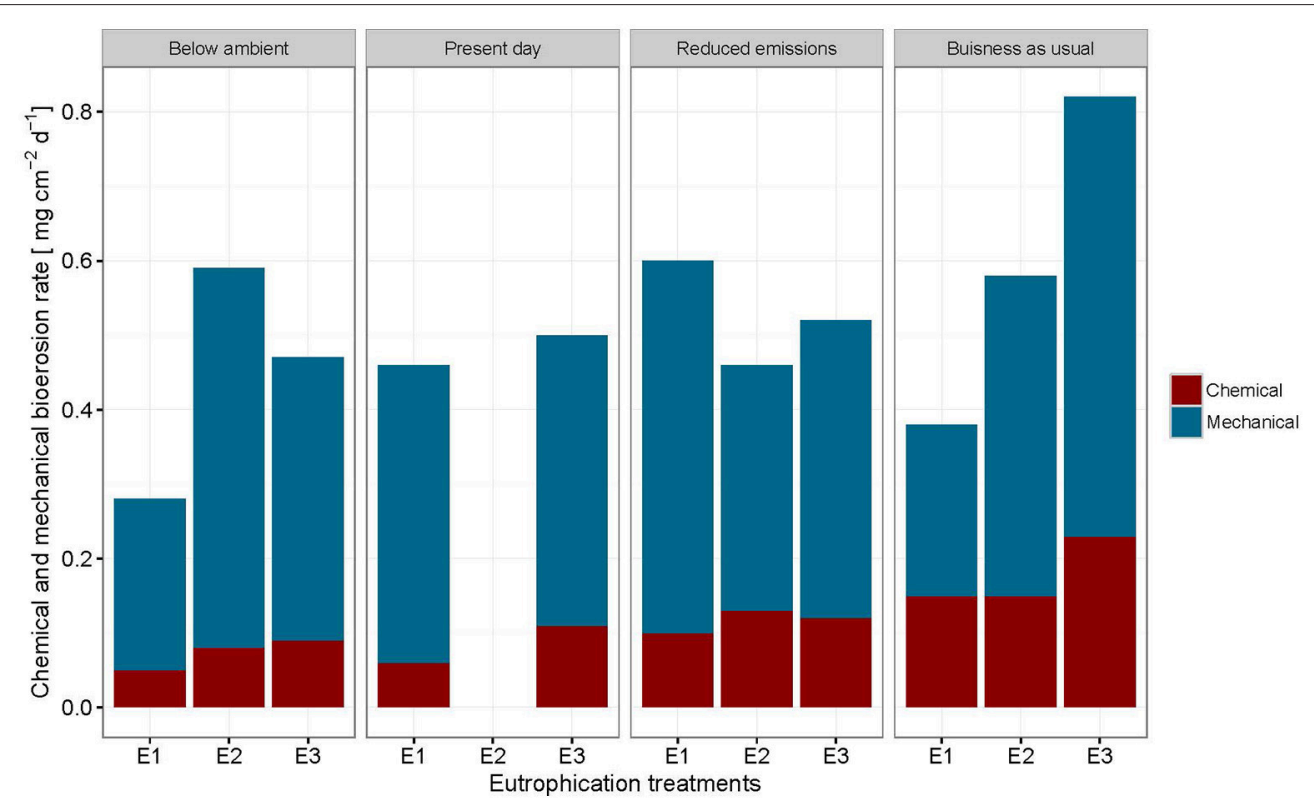

FIGURE 5 | Sum of chemical and mechanical bioerosion in $\mathrm{mg} \mathrm{cm}^{-2} \mathrm{~d}^{-1}$ for each $\mathrm{pCO}_{2}$ and eutrophication scenario. Mechanical bioerosion rates were estimated using the weight of chips collected during $6 \mathrm{~h}$ incubations. Chips were only collected for table $\mathrm{A}$ and $\mathrm{B}$ during the day and night $(\mathrm{N}=44)$. Chemical bioerosion rates were calculated from $\Delta \mathrm{A}_{\mathrm{T}}$ in incubations $(N=59)$. Day $(24 \mathrm{~h})$ rates were calculated by multiplying day and night mechanical and chemical hourly rates by 12 and adding them together for each $\mathrm{pCO}_{2}$ and eutrophication scenario.

carbonate dissolution, photosynthesis must therefore supply a high fraction of the energetic costs of the bioerosion process which may include ATP usage for active $\mathrm{Ca}^{2+}$ and/or active proton pumping (Guida and Garcia-Pichel, 2016). Higher rates during the day at low and ambient $\mathrm{pCO}_{2}$ indicate that the benefit of acquired energy from photosynthetic activity 


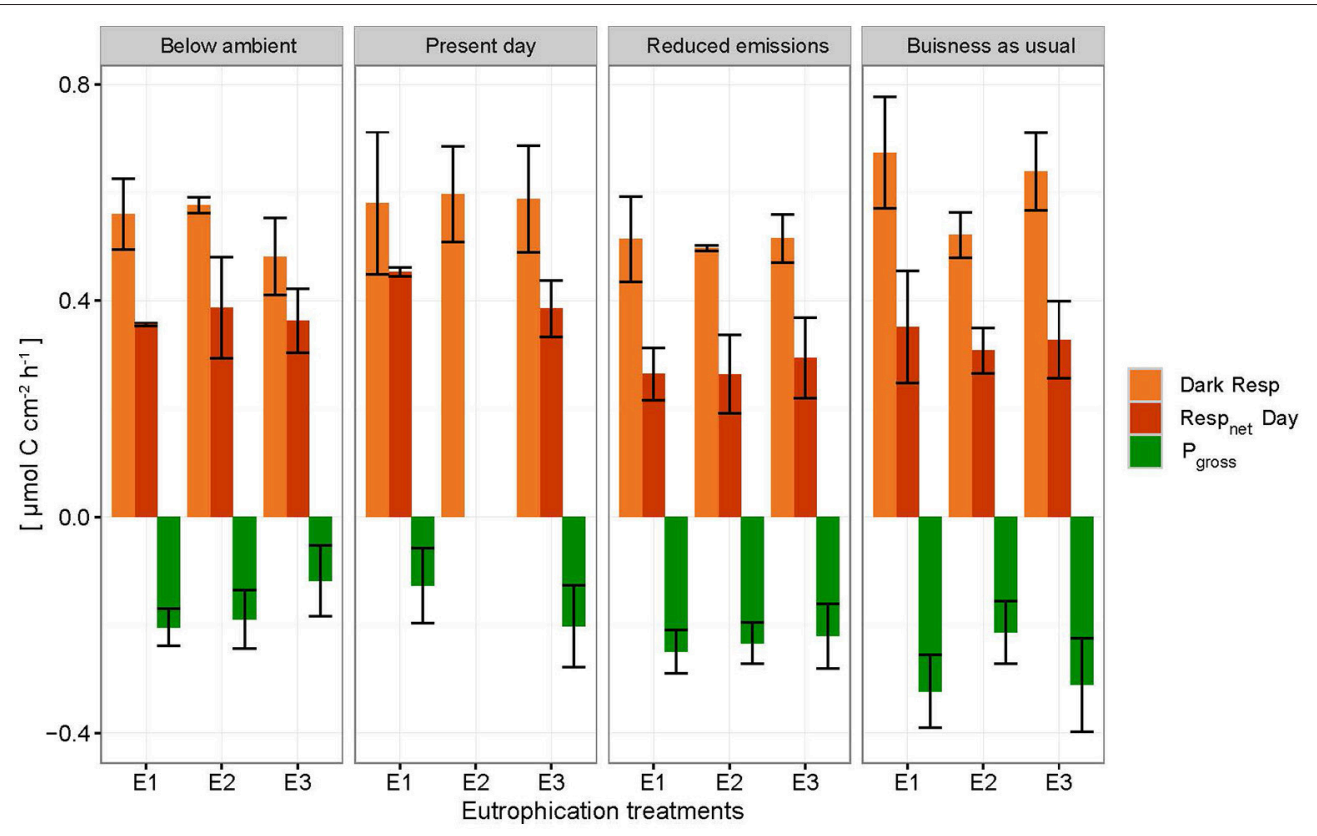

FIGURE 6 | Net respiration rates (Respnet) during the day (dark orange), dark respiration rates (dark Resp) during the night (light orange) and gross photosynthesis (Pgross) of the holobiont (sponge + symbionts) $\pm \mathrm{SEM}$ for each $\mathrm{pCO}_{2}$ and eutrophication scenario. Pgross was derived from the net respiration of the symbionts (shown as negative respiration in the figure by assuming that 1 mole $\mathrm{CO}_{2}$ respired during the night equals 1 mole $\mathrm{O}_{2}$ produced during the day).

exceeds the benefit of increased $p \mathrm{CO}_{2}$ levels at night due to respiration.

Due to the sponge's energetic dependence on photosynthates for enhanced bioerosion activity, the capacity of phototrophic sponges to excavate may be particularly sensitive to environmental changes impacting photosynthesis. Our results suggest that photosynthesis is enhanced with increased $\mathrm{pCO}_{2}$ (Figure 6), possibly due to a switch from $\mathrm{HCO}_{3}^{-}$to $\mathrm{CO}_{2}$ uptake. Fang et al. (2014) describes a greater supply of photosynthetic products from symbionts in the "reduced emissions" scenario $\left(p \mathrm{CO}_{2}=645 \mu \mathrm{atm}\right.$, temperature $\left.=28.4^{\circ} \mathrm{C}\right)$ to meet higher metabolic demands. Photosynthetic products by symbionts may be used for biosynthesis and respiration by the zooxanthellae or transferred to the associated sponge where it is used for metabolic maintenance via respiration or growth (Fang et al., 2014).

Despite enhanced photosynthetic rates with rising $p \mathrm{CO}_{2}$, daytime chemical rates did not seem to benefit from this boost in energy supply as they were found to be comparable and even lower than night-time rates. The relationship between the sponge and its symbionts regarding bioerosional processes seems to change at higher $p \mathrm{CO}_{2}$. We hypothesize that the increase in local $\mathrm{pH}$ associated with enhanced photosynthesis may be too large to be balanced out by local respiration acidification. In other words, the increased photosynthetic activity may have an antagonistic effect with respect to acidification during day-time due to higher uptake of $\mathrm{CO}_{2}$ by the symbionts. Borges and Gypens (2010) argued that the effect of enhanced primary production on carbon cycling can counter the effect of ocean acidification. Increased respiration might stimulate primary production by increased translocation of $\mathrm{CO}_{2}$ of the sponge to the symbionts. The antagonistic behavior of trends observed between respiration at night and net respiration during the day with rising $p \mathrm{CO}_{2}$, is attributed to enhanced photosynthesis resulting in greater $\mathrm{CO}_{2}$ fixation by photosymbionts.

Furthermore, competition for dissolved inorganic carbon species may occur between bioerosion and photosynthetic activity by the symbionts.

\section{Comparison and Extrapolation of Bioerosion Rates}

Estimates of chemical and mechanical bioerosion for C. caribbaea are comparable to those calculated for $C$. orientalis under a range of $\mathrm{CO}_{2}$ concentrations (Fang et al., 2013a; Wisshak et al., 2013, 2014). This is consistent with the membership of C. caribbaea to the Cliona viridis-complex (Schönberg, 2002). Our chemical rates ranged from 0.06 to $0.15 \mathrm{mg} \mathrm{cm}^{-2}$ day $^{-1}$ from present day to business-as-usual $p \mathrm{CO}_{2}$ levels. Estimates by Fang et al. (2013a) ranged from 0.08 to $0.3 \mathrm{mg} \mathrm{cm}^{-2}$ day $^{-1}$ while rates by Wisshak et al. (2014) ranged from 0.02 to $0.26 \mathrm{mg} \mathrm{cm}^{-2}$ day $^{-1}$. Mechanical rates from Fang ranged from 0.12 to 0.16 $\mathrm{mg} \mathrm{cm}{ }^{-2}$ day $^{-1}$ whilst our results ranged from 0.23 to $0.5 \mathrm{mg}$ $\mathrm{cm}^{-2}$ day $^{-1}$ (in E1). Total bioerosion rates from this study were nearly three times higher than those of Fang et al. (2013a) and Wisshak et al. (2014). Discrepancies between results can be attributed to differences in the methodology and calculations between these experiments. For instance, Wisshak et al. (2014) only conducted dark incubations which would explain the relatively low rates at ambient $p \mathrm{CO}_{2}$. These inconsistencies in the methodology between experiments are complicating 
comparison between results from different studies. Therefore, there is a need for method standardization regarding sponge bioerosion rates experiments. In addition, incubation methods are affecting sponges and are preventing accurate determination of rates. Up to now, closed incubations have been sufficient to observe relative variation between $\mathrm{pCO}_{2}$, temperature and eutrophication treatments. This sheds light on how boring sponges may react to future environmental changes. However, if we are to quantify such reaction, it is essential that rates are more accurately measured. Using semi enclosed incubation chambers may increase accuracy of chemical rates greatly. As the method involved in quantifying mechanical bioerosion rates is regarded as untrustworthy, collection of chips should be applied to a longer stretch in time.

Extrapolations should be treated with caution as it is an enormous jump to go from $6 \mathrm{~h}$ incubations to yearly estimates (McElhany, 2016), especially considering how seasonality and therefore different irradiance levels of light may impact bieoerosion rates of photosymbiotic sponges. Still, when extrapolating chemical bioerosion rates from our experiment to yearly estimates, rates in the present-day (PD) $p \mathrm{CO}_{2}$ scenario and in the business as usual (BU) scenario ranged from 0.22 to $0.55 \mathrm{~kg} \mathrm{~m}^{-2}$ year $^{-1}$ in $\mathrm{E} 1$ and from 0.40 to $0.84 \mathrm{~kg} \mathrm{~m}^{-2}$ year $^{-1}$ in E3. This corresponds to a doubling of rates by the end of this century. Even in a slightly more optimistic scenario, where $\mathrm{CO}_{2}$ emissions are reduced, chemical bioerosion rates would increase by $50 \%$ compared to present rates. However, combined effects of $p \mathrm{CO}_{2}$ and eutrophication, result in rates ranging from $0.22 \mathrm{~kg}$ $\mathrm{m}^{-2}$ year $^{-1}$ in PD: E1 to $0.84 \mathrm{~kg} \mathrm{~m}^{-2}$ year $^{-1}$ in BU: E3 which nearly corresponds to a quadrupling in chemical bioerosion rates.

\section{CONCLUSIONS}

Considering ongoing ocean acidification, combined with increasing coastal eutrophication around Caribbean islands, these finding suggests that sponge bioerosion will increase in the next century. The combined effect of OA and eutrophication on bioerosional activity was not synergetic but additive. Enhanced bioerosion in future oceans together with reduced calcifying potential of corals will inevitably tip the balance between reef accretion and bioerosion processes toward net loss of carbonate structure.

\section{REFERENCES}

Borges, A. V., and Gypens, N. (2010). Carbonate chemistry in the coastal zone responds more strongly to eutrophication than ocean acidification. Limnol. Oceanogr. 55, 346-353. doi: 10.4319/lo.2010.55. 1.0346

Bruno, J. F., Sweatman, H., Precht, W. F., Selig, E. R., and Schutte, V. G. (2009). Assessing evidence of phase shifts from coral to macroalgal dominance on coral reefs. Ecology 90, 1478-1484. doi: 10.1890/08-1781.1

Cai, W.-J., Hu, X., Huang, W.-J., Murrell, M. C., Lehrter, J. C., Lohrenz, S. E., et al. (2011). Acidification of subsurface coastal waters enhanced by eutrophication. Nat. Geosci. 4, 766-770. doi: 10.1038/ngeo1297

Camacho, F. G., Chileh, T., García, M., Mirón, A. S., Belarbi, E., Gómez, A. C., et al. (2006). Sustained growth of explants from Mediterranean sponge
Results from our incubation experiments increases our understanding of the effect of symbionts on bioerosional activity. Greater chemical bioerosion during the day at low and ambient $p \mathrm{CO}_{2}$ suggest that the energy gained by photosynthetic activity is fueling a high fraction of the metabolic cost at the site of erosion which may include ATP usage for active $\mathrm{Ca}^{2+}$ and/or active proton pumping. At higher $\mathrm{pCO}_{2}$, enhanced photosynthesis appears to have an antagonistic effect with respect to acidification due to higher uptake of $\mathrm{CO}_{2}$ by the symbionts. Finally, our results stress the need to explore in more detail the role of light on the regulation of photosymbiotic sponge bioerosion rates.

\section{AUTHOR CONTRIBUTIONS}

Data collection: AW and DdB; Data analysis: AW; Interpretation of the data: AW, SvH, DdB, FvD, GR, and LdN; Drafting work: AW; Critical revision: FvD, SvH, GR, and LdN; Final approval: AW, SvH, DdB, FvD, GR, and LdN; Agreement to be accountable for all aspects of the work AW, SvH, DdB, FvD, GR, and LdN.

\section{ACKNOWLEDGMENTS}

We would like to thank two reviewers for their constructive comments which improve the initial manuscript. We thank the Caribbean Netherlands Science Institute (CNSI) for hosting the experiment and especially Johan Staple for his support. We also thank Masru Spanner for the nutrient analyses and Santiago Gonzalez for the dissolved organic carbon analyses and Paul Peters for field assistance. Bob Koster is gratefully acknowledged for the design and development of the $\mathrm{pCO}_{2}$ set-up just as the NIOZ workshop whose help and work was crucial for the construction of the experimental set-up. This work is supported by the Gravitation grant NESSC from the Dutch Ministry of Education, Culture and Science. External funding for this project was provided by the Netherlands Organization for Scientific Research (NWO grants 858.14.021 and 858.14.022).

\section{SUPPLEMENTARY MATERIAL}

The Supplementary Material for this article can be found online at: http://journal.frontiersin.org/article/10.3389/fmars. 2017.00311/full\#supplementary-material

Crambe crambe cultured in vitro with enriched RPMI 1640. Biotechnol. Prog. 22, 781-790. doi: 10.1021/bp050341m

Carballo, J. L., Bautista-Guerrero, E., and Leyte-Morales, G. E. (2008). Boring sponges and the modeling of coral reefs in the east Pacific Ocean. Mar. Ecol. Prog. Ser. 356, 113-122. doi: 10.3354/meps07276

Chisholm, J. R., and Gattuso, J. P. (1991). Validation of the alkalinity anomaly technique for investigating calcification of photosynthesis in coral reef communities. Limnol. Oceanogr. 36, 1232-1239. doi: 10.4319/lo.1991.36.6.1232

Cyronak, T., Santos, I. R., Erler, D. V., Maher, D. T., and Eyre, B. D. (2014). Drivers of $p \mathrm{CO}_{2}$ variability in two contrasting coral reef lagoons: the influence of submarine groundwater discharge. Global Biogeochem. Cycles 28, 398-414. doi: 10.1002/2013GB004598

De Bakker, D. M., van Duyl, F. C., Bak, R. P. M., Nugues, M. M., Nieuwland, G., and Meesters, E. H. (2017). 40 years of benthic community change on the caribbean 
reefs of curaçao and bonaire: the rise of slimy cyanobacterial mats. Coral Reefs 36, 355-367. doi: 10.1007/s00338-016-1534-9

De Goeij, J. M., and Van Duyl, F. C. (2007). Coral cavities are sinks of dissolved organic carbon (DOC). Limnol. Oceanogr. 52, 2608-2617. doi: 10.4319/lo.2007.52.6.2608

Dickson, A. G., and Millero, F. J. (1987). A comparison of the equilibrium constants for the dissociation of carbonic acid in seawater media. Deep Sea Res. A Oceanogr. Res. Pap. 34, 1733-1743. doi: 10.1016/0198-0149(87)90021-5

Dickson, A. G., Sabine, C. L., and Christian, J. R. (2007). Guide to best Practices for Ocean $\mathrm{CO}_{2}$ Measurements. Sidney, BC: PICES Special Publication 3.

Dove, S. G., Kline, D. I., Pantos, O., Angly, F. E., Tyson, G. W., and HoeghGuldberg, O. (2013). Future reef decalcification under a business-as-usual CO2 emission scenario. Proc. Natl. Acad. Sci. U.S.A. 110, 15342-15347. doi: $10.1073 /$ pnas. 1302701110

Duckworth, A. R., and Peterson, B. J. (2013). Effects of seawater temperature and $\mathrm{pH}$ on the boring rates of the sponge Cliona celata in scallop shells. Mar. Biol. 160, 27-35. doi: 10.1007/s00227-012-2053-Z

Edinger, E. N., Limmon, G. V., Jompa, J., Widjatmoko, W., Heikoop, J. M., and Risk, M. J. (2000). Normal coral growth rates on dying reefs: are coral growth rates good indicators of reef health? Mar. Pollut. Bull. 40, 404-425. doi: 10.1016/S0025-326X(99)00237-4

Enochs, I. C., Manzello, D. P., Carlton, R. D., Graham, D. M., Ruzicka, R., and Colella, M. A. (2015). Ocean acidification enhances the bioerosion of a common coral reef sponge: implications for the persistence of the Florida Reef Tract. Bull. Mar. Sci. 91, 271-290. doi: 10.5343/bms.2014.1045

Erwin, P. M., and Thacker, R. W. (2008). Phototrophic nutrition and symbiont diversity of two Caribbean sponge-cyanobacteria symbioses. Mar. Ecol. Prog. Ser. 362, 139-147. doi: 10.3354/meps07464

Fang, J. K. H., Mello-Athayde, M. A., Schonberg, C. H., Kline, D. I., HoeghGuldberg, O., and Dove, S. (2013a). Sponge biomass and bioerosion rates increase under ocean warming and acidification. Glob. Chang. Biol. 19, 3581-3591. doi: 10.1111/gcb.12334

Fang, J. K. H., Schönberg, C. H. L., Hoegh-Guldberg, O., and Dove, S. (2016). Daynight ecophysiology of the photosymbiotic bioeroding sponge Cliona orientalis Thiele, 1900. Mar. Biol. 163, 1-12. doi: 10.1007/s00227-016-2848-4

Fang, J. K. H., Schönberg, C. H. L., Kline, D. I., Hoegh-Guldberg, O., and Dove, S. (2013b). Methods to quantify components of the excavating spongeCliona orientalisThiele, 1900. Mar. Ecol. 34, 193-206. doi: 10.1111/maec.12005

Fang, J. K. H., Schonberg, C. H. L., Mello-Athayde, M. A., Hoegh-Guldberg, O., and Dove, S. (2014). Effects of ocean warming and acidification on the energy budget of an excavating sponge. Glob. Chang. Biol. 20, 1043-1054. doi: $10.1111 /$ gcb.12369

Freeman, C. J., and Thacker, R. W. (2011). Complex interactions between marine sponges and their symbiotic microbial communities. Limnol. Oceanogr. 56, 1577-1586. doi: 10.4319/lo.2011.56.5.1577

Garcia-Pichel, F. (2006). Plausible mechanisms for the boring on carbonates by microbial phototrophs. Sediment. Geol. 185, 205-213. doi: 10.1016/j.sedgeo.2005.12.013

Garcia-Pichel, F., Ramirez-Reinat, E., and Gao, Q. (2010). Microbial excavation of solid carbonates powered by P-type ATPase mediated transcellular $\mathrm{Ca}^{2+}$ transport. Proc. Natl. Acad. Sci. U.S.A. 107, 21749-22154. doi: 10.1073/pnas.1011884108

Gast, G. J., Jonkers, P., Van Duyl, F., and Bak, R. P. M. (1999). Bacteria, flagellates and nutrients in island fringing coral reef waters: influence of the ocean, the reef and eutrophication. Bull. Mar. Sci. 65, 523-538.

Gattuso, J.-P., and Hansson, L. (2011). "Ocean acidification: background and history," in Ocean Acidification, eds J.-P. Gattuso and L. Hansson (Oxford: Oxford University Press), 1-20.

Gattuso, J.-P., Frankignoulle, M., Bourge, I., Romaine, S., and Buddemeier, R. (1998). Effect of calcium carbonate saturation of seawater on coral calcification. Glob. Planet. Change 18, 37-46. doi: 10.1016/S0921-8181(98)00035-6

Gorgula, S. K., and Connell, S. D. (2004). Expansive covers of turf-forming algae on human-dominated coast: the relative effects of increasing nutrient and sediment loads. Mar. Biol. 145, 613-619. doi: 10.1007/s00227-004-1335-5

Govers, L. L., Lamers, L. P., Bouma, T. J., de Brouwer, J. H., and van Katwijk, M. M. (2014). Eutrophication threatens Caribbean seagrassesan example from Curaçao and Bonaire. Mar. Pollut. Bull. 89, 481-486. doi: 10.1016/j.marpolbul.2014.09.003
Guida, B. S., and Garcia-Pichel, F. (2016). Extreme cellular adaptations and cell differentiation required by a cyanobacterium for carbonate excavation. Proc. Natl. Acad. Sci. U.S.A. 113, 5712-5717. doi: 10.1073/pnas.1524687113

Hill, M. S. (1996). Symbiotic zooxanthellae enhance boring and growth rates of the tropical sponge Anthosigmella varians forma varians. Mar. Biol. 125, 649-654. doi: 10.1007/BF00349246

Hill, M. S. (2014). Production possibility frontiers in phototroph: heterotroph symbioses: trade-offs in allocating fixed carbon pools and the challenges these alternatives present for understanding the acquisition of intracellular habitats. Front. Microbiol. 5:357. doi: 10.3389/fmicb.2014.00357

Hoegh-Guldberg, O., Mumby, P. J., Hooten, A. J., Steneck, R. S., Greenfield, P., Gomez, E., et al. (2007). Coral reefs under rapid climate change and ocean acidification. Science 318, 1737-1742. doi: 10.1126/science.1152509

Holmes, K. E. (2000). Effects of eutrophication on bioeroding sponge communities with the description of new West Indian sponges, Cliona spp. (Porifera: Hadromerida: Clionidae). Invert. Biol. 119, 125-138. doi: 10.1111/j.1744-7410.2000.tb00001.x

Hudson, J. (1977). "Long-term bioerosion rates on a Florida reef: a new method," in Proceedings of the 3rd International Coral Reef Symposium (Miami), 491-497.

Hughes, T. P. (1994). Catastrophes, phase shifts, and large-scale degradation of a Caribbean coral reef. Science 265, 1547-1551. doi: $10.1126 /$ science.265.5178.1547

Hydes, D., Aoyama, M., Aminot, A., Bakker, K., Becker, S., Coverly, S., et al. (2010). Determination of Dissolved Nutrients (N, P, Si) in Seawater with High Precision and Inter-Comparability Using Gas-Segmented Continuous Flow Analysers. The GOSHIP Repeat Hydrography Manual: a Collection of Expert Reports and Guidelines. IOCCP report number 14, ICPO publication series number 134, UNESCO-IOC, (Paris)

Jacques, T., and Pilson, M. (1980). Experimental ecology of the temperate scleractinian coral Astrangia danae I. Partition of respiration, photosynthesis and calcification between host and symbionts. Mar. Biol. 60, 167-178. doi: 10.1007/BF00389160

Johnson, K., Wills, K., Butler, D., Johnson, W., and Wong, C. (1993). Coulometric total carbon dioxide analysis for marine studies: maximizing the performance of an automated gas extraction system and coulometric detector. Mar. Chem. 44, 167-187. doi: 10.1016/0304-4203(93)90201-X

Kleypas, J. A., and Langdon, C. (2006). "Coral reefs and changing seawater carbonate chemistry," in Coastal and Estuarine Studies: Coral Reefs and Climate Change Science and Management, Vol. 61, eds J. T. Phinney, O. HoeghGuldberg, J. A. Kleypas, W. Skirving, and A. Strong (American Geophysical Union), 73-110.

Kuffner, I. B., and Paul, V. J. (2001). Effects of nitrate, phosphate and iron on the growth of macroalgae and benthic cyanobacteria from Cocos Lagoon, Guam. Mar. Ecol. Prog. Ser. 222, 63-72. doi: 10.3354/meps 222063

Lapointe, B. E., and Mallin, M. (2011). Nutrient Enrichment and Eutrophication on Fringing Coral Reefs of Bonaire and Curaçao, Netherlands Antilles. Report to the United Nations Environment Programme for the NACRI Coral Reef Monitoring Program. Pierce, FL; Harbor Branch Oceanographic Institute.

Le Quéré, C., Andres, R. J., Boden, T., Conway, T., Houghton, R. A., House, J. I., et al. (2013). The global carbon budget 1959-2011. Earth Syst. Sci. Data 5, 165-185, doi: 10.5194/essd-5-165-2013

Le Quéré, C., Moriarty, R., Andrew, R. M., Canadell, J. G., Sitch, S., Korsbakken, J. I., et al. (2015). Global carbon budget 2015. Earth Syst. Sci. Data 7, 349-396. doi: 10.5194/essd-7-349-2015

MacGeachy, J. K., and Stearn, C. W. (1976). Boring by macro-organisms in the coral Montastrea annularis on Barbados Reefs. Int. Rev. Gesamten Hydrobiol. Hydrogr. 61, 715-745. doi: 10.1002/iroh.19760610602

Maldonado, M., Ribes, M., and van Duyl, F. C. (2012). 3 Nutrient fluxes through sponges: biology, budgets, and ecological implications. Adv. Mar. Biol. 62:113. doi: 10.1016/B978-0-12-394283-8.00003-5

McElhany, P. (2016). $\mathrm{CO}_{2}$ sensitivity experiments are not sufficient to show an effect of ocean acidification. ICES J. Mar. Sci. 74, 926-928. doi: 10.1093/icesjms/fsw085

Mintrop, L., Pérez, F. F., González-Dávila, M., Santana-Casiano, J. M., and Körtzinger, A. (2000). Alkalinity determination by potentiometry: intercalibration using three different methods. Cienc. Mar. 26, 23-37. doi: $10.7773 / \mathrm{cm} . v 26 \mathrm{i} 1.573$ 
Mueller, B., de Goeij, J. M., Vermeij, M. J., Mulders, Y., van der Ent, E., Ribes, M., et al. (2014). Natural diet of coral-excavating sponges consists mainly of dissolved organic carbon (DOC). PLoS ONE 9:e90152. doi: 10.1371/journal.pone.0090152

Nasonov (1924). Sur l'eponge Perforantes Clione Stationis Nason.et le Procede du Creusement des Galeries dans les Valves des Huitres. Moscow: C R. Academy Science Russia, 113-115.

Nava, H., and Carballo, J. L. (2008). Chemical and mechanical bioerosion of boring sponges from Mexican Pacific coral reefs. J. Exp. Biol. 211(Pt. 17), 2827-2831. doi: $10.1242 /$ jeb.019216

Pandolfi, J. M., Connolly, S. R., Marshall, D. J., and Cohen, A. L. (2011). Projecting coral reef futures under global warming and ocean acidification. Science 333, 418-422. doi: 10.1126/science.1204794

Perry, C. T., Murphy, G. N., Kench, P. S., Edinger, E. N., Smithers, S. G., Steneck, R. S., et al. (2014). Changing dynamics of Caribbean reef carbonate budgets: emergence of reef bioeroders as critical controls on present and future reef growth potential. Proc. R. Soc. B 281, 2014-2018. doi: 10.1098/rspb.2014.2018

Pomponi, S. A. (1980). Cytological mechanisms of calcium carbonate excavation by boring sponges. Int. Rev. Cytol. 65, 301-319. doi: 10.1016/S0074-7696(08)61963-4

R Core Team (2013). R Foundation for Statistical Computing. Vienna.

Ries, J. B., Cohen, A. L., and McCorkle, D. C. (2009). Marine calcifiers exhibit mixed responses to $\mathrm{CO}_{2}$-induced ocean acidification. Geology 37, 1131-1134. doi: $10.1130 / \mathrm{G} 30210 \mathrm{~A} .1$

Rützler, K., and Rieger, G. (1973). Sponge burrowing: fine structure of Cliona lampa penetrating calcareous substrata. Mar. Biol. 21, 144-162. doi: 10.1007/BF00354611

Schönberg, C. H. L. (2000). "Sponges of the 'Cliona viridis complex'-a key for Species Identification," in Proceedings of 9th International Coral Reef Symposium (Bali), 295-299.

Schönberg, C. H. L. (2002). Substrate effects on the bioeroding demosponge Cliona orientalis. 1. Bioerosion rates. Mar. Ecol. 23, 313-326. doi: 10.1046/j.1439-0485.2002.02811.x

Schönberg, C. H. L. (2006). "Growth and erosion of the zooxanthellate Australian bioeroding sponge Cliona orientalis are enhanced in light," in Proceedings of the 10th International Coral Reef Symposium (Napoli), 168-174.

Schönberg, C. H. L. (2008). "A history of sponge erosion: from past myths and hypotheses to recent approaches," in Current Developments In Bioerosion, eds M. Wisshak, and L. Tapanila (Berlin; Heidelberg: Springer), 165-202.

Schönberg, C. H. L., Fang, J. K. H., Carreiro-Silva, M., Tribollet, A., and Wisshak, M. (2017). Bioerosion: the other ocean acidification problem. ICES J. Marine Sci. 74, 895-925. doi: 10.1093/icesjms/fsw254

Smith, S. V., and Key, G. S. (1975). Carbon dioxide and metabolism in marine environments. Limnol. Oceanogr. 20, 493-495. doi: 10.4319/lo.1975.20.3.0493

Solomon, S. (2007). Climate change 2007-the Physical Science Basis: Working group I Contribution to the Fourth Assessment Report of the IPCC. Cambridge, UK: Cambridge University Press.
Sommerville, L., and Hartshorne, D. (1986). Intracellular calcium and smooth muscle contraction. Cell Calcium 7, 353-364. doi: 10.1016/0143-4160(86)90038-2

Van Duyl, F. C., and Gast, G. J. (2001). Linkage of small-scale spatial variations in DOC, inorganic nutrients and bacterioplankton growth with different coral reef water types. Aquat. Microbiol. Ecol. 24, 17-26. doi: 10.3354/ ame 024017

Vermeij, M. J., Van Moorselaar, I., Engelhard, S., Hörnlein, C., Vonk, S. M., and Visser, P. M. (2010). The effects of nutrient enrichment and herbivore abundance on the ability of turf algae to overgrow coral in the Caribbean. PLoS ONE 5:e14312. doi: 10.1371/journal.pone.0014312

Veron, J. E. N. (2011). Ocean Acidification and Coral Reefs: an emerging big picture. Diversity 3, 262-274. doi: 10.3390/d3020262

Weisz, J. B., Massaro, A. J., Ramsby, B. D., and Hill, M. S. (2010). Zooxanthellar symbionts shape host sponge trophic status through translocation of carbon. Biol. Bull. 219, 189-197. doi: 10.1086/BBLv219n3p189

Wisshak, M., and Tapanila, L. (2008). Current Developments in Bioerosion. Berlin: Springer Science \& Business Media.

Wisshak, M., Schönberg, C. H. L., Form, A. U., and Freiwald, A. (2014). Sponge bioerosion accelerated by ocean acidification across species and latitudes? Helgol. Mar. Res. 68:253. doi: 10.1007/s10152-014-0385-4

Wisshak, M., Schönberg, C. H. L., Form, A. U., and Freiwald, A. (2013). Effects of ocean acidification and global warming on reef bioerosionlessons from a clionaid sponge. Aquat. Biol. 19, 111-127. doi: 10.3354/ ab00527

Wisshak, M., Schönberg, C. H. L., Form, A. U., and Freiwald, A. (2012) Ocean acidification accelerates reef bioerosion. PLoS ONE 7:e45124. doi: 10.1371/journal.pone.0045124

Yeakel, K. L., Andersson, A. J., Bates, N. R., Noyes, T. J., Collins, A., and Garley, R. (2015). Shifts in coral reef biogeochemistry and resulting acidification linked to offshore productivity. Proc. Natl. Acad. Sci. 112, 14512-14517. doi: 10.1073/pnas.1507021112

Zundelevich, A., Lazar, B., and Ilan, M. (2007). Chemical versus mechanical bioerosion of coral reefs by boring sponges-lessons from Pione cf. vastifica. J. Exp. Biol. 210(Pt. 1), 91-96. doi: 10.1242/jeb.02627

Conflict of Interest Statement: The authors declare that the research was conducted in the absence of any commercial or financial relationships that could be construed as a potential conflict of interest.

Copyright (๑) 2017 Webb, van Heuven, de Bakker, van Duyl, Reichart and de Nooijer. This is an open-access article distributed under the terms of the Creative Commons Attribution License (CC BY). The use, distribution or reproduction in other forums is permitted, provided the original author(s) or licensor are credited and that the original publication in this journal is cited, in accordance with accepted academic practice. No use, distribution or reproduction is permitted which does not comply with these terms. 